\title{
İstibdâdî İdârenin Gizli Enstrümanlarından Hafiyelik ve Jurnalin Reşat Nuri Güntekin'in Romanlarına Yansıması
}

\section{Reflections Spying and Reporting The Secret Instruments of Control in Reşat Nuri Güntekin's Novels}

\author{
Yasemin ALPER $^{1}$ (1)
}

${ }^{1}$ Sorumlu yazar/Corresponding author: Yasemin Alper (Dr.),

Ankara, Türkiye

E-posta: yaseminalper16@gmail.com

ORCID: 0000-0001-7640-2696

Başvuru/Submitted: 26.06 .2021

Revizyon Talebi/Revision Requested: 01.09.2021

Son Revizyon/Last Revision Received: 06.10.2021

Kabul/Accepted: 07.10.2021

Online Yayın/Published Online: 04.12.2021

Atıf/Citation: Alper, Yasemin. "İstibdâdî Idârenin Gizli Enstrümanlarından Hafiyelik ve Jurnalin Reşat Nuri Güntekin'in Romanlarına Yansıması.." Türkiyat Mecmuası-Journal of Turkology 31, 2 (2021): 649-680. https://doi.org/10.26650/iuturkiyat.991913

\section{ÖZ}

Osmanlı tarihinde devlet adına bilgi toplama faaliyetlerinin geçmişi hayli eskidir. Geniş coğrafyaya yayılmış bir imparatorluğun denetlenmesi, valilerden sade vatandaşa kadar hemen herkes hakkında bilgi edinilmesi, halkın beklenti ve şikâyetlerinin öğrenilmesi II. Mahmud Dönemi'nde (1808-1839) bir ihtiyaç olarak görülür. Şehir merkezleri, kaza ve kasabaların yöneticilerinden bu amaçla alınan jurnaller, İstanbul'a ulaştırılır. Jurnal hazırlama faaliyetleri, devletin içişlerinde genellikle insanların memnuniyetini ölçmeye yönelik yapılırken zamanla iktidar ve çıkar mücadelelerinin bir aracı hâline gelir. II. Abdülhamid Dönemi'nde (1876-1909) kurumsal bir yapı olarak öne çıkan hafiyelik; karmaşık, aydınlatılması zor bir görünüme bürünür ve pek çok kesim için korku ile anılan bir konuma yerleşir. Iş̧te, kahvede, sokakta hatta evlerde yapılan devlet içerikli her türlü konuşma, hafiyelerin jurnal mevzuudur. Jurnaller; hafiyelere ikbal, imtiyaz sağlarken jurnallenen kişiler için tecrid, tevkif ve sürgün nedeni olur. Toplumu derinden etkileyen "jurnalcilik" olgusu, Reşat Nuri'nin kalemine de yansır. Sanatçının sosyal ve siyâsî hayatın çeşitli dönemlerini gerçekçi örneklerle yansıtan romanları; politik, sosyolojik ve kültürel açılardan tetkik edilebilecek pek çok konuyu içerir. Gizlice yapılan hafiyelik ve jurnal, dönemin siyâsî durumunu gösteren kurgusal hayat sahneleriyle görünür hâle gelir. Çoğu tarihî gerçekliği olan konuların roman kurgusu içinde işlenişi, Güntekin'in eserlerine hem edebî hem tarihî belge değeri yükler.

Anahtar kelimeler: Hafiyelik, Jurnal, İstibdâd, Reşat Nuri Güntekin, Roman

\section{ABSTRACT}

The Ottoman state had a long history of information gathering activities on its behalf. During Mahmut II's reign (1808-1839), given the geographical extent of the empire, it was seen as a necessity to collect information about everyone from governors to ordinary citizens and to learn about the expectations and complaints of the population. Accordingly, reports collected from the administrators of city centers, districts, and towns were delivered to Istanbul. While secret information gathering activities in this period were generally undertaken to gauge popular satisfaction with the internal affairs of the state, they gradually became a tool of power and interest struggles. The role of the spy, which came to the fore as an institutional structure during the Abdulhamid 
period (1876-1909), was complex and many aspects remain obscure. The spy was in a positionthat aroused fear among many people. All kinds of state-related comments, whether made at work, in cafes, on the street, or even in houses, might be the subject of reports by spies. While these reports conferred various privileges on spies, they could also trigger the arrest and exile of the people who were reported. The handling of the subject matter in Güntekin's novels, most of which is based on historical reality, endows them with both literary and historical value. The novels, in which social and political life during various periods is represented using realistic examples, include many subjects that can be examined from an anthropological perspective. The spy and the spy's reports, which are among Güntekin's subjects and have enigmatic aspects, are revealed through fictional life scenes that demonstrate the political situation of the period.

Keywords: Spying, Reporting, Control, Reşat Nuri Güntekin, Novel

\section{EXTENDED ABSTRACT}

The Ottoman Empire was ruled for 33 years, between 1876 and 1909, by Abdulhamid II. As a political actor, he made quite a name for himself among the Ottoman sultans and was perceived as the greatest enemy of some and the most cherished friend of others during his lifetime. While some perceived Abdulhamid as an oppressive, censorious, and autocratic personality because of his actions, others viewed him as a statesman and spiritual personality and would have considered rebellion against him equivalent to rebellion against Allah. Abdulhamid established a security service, the Umur-u Hafiye, to avoid the negative situations experienced by previous sultans and to suppress popular fears and delusions. Over time, however, the Umur-u Hafiye became a tool for sordid dealings and conflicts of interest. The organization, which started to be perceived as a cancer in society, caused various social and political crises until it was suspended by order of the state on July 31, 1908.

Reşat Nuri Güntekin, who liked to reflect on the political and social situation of his period in his works, frequently treated spying and reporting as secondary elements in his various novels. When Güntekin's novels are examined as a whole, in line with concepts of espionage and information collection, it may be understood that the author is painting a general picture that reflects social and political conditions under an autocratic government. This painting, drawn from the public's perspective, is black and white, not color. The black part consists of the palace and its surroundings, while the white consists of dissidents or those thought to be dissidents. The public, the main figure in the painting, is surrounded by absolute authority. Some were spied upon, and some were reported on. In the later parts of this panorama, there are enlightened people who were nonetheless detained and sometimes exiled to regions near and far.

Surveillance creates deep distrust, anxiety, and fear among people. It thus damages the unity and solidarity of asociety over time, turning people against each other as well as triggering prohibitions, arrests, and exiles. A common auxiliary element in the novels of Reşat Nuri Güntekin is the observation of society's problems with a keen intellect. Güntekin, who writes rationally, intelligently, and optimistically, only induces a feeling of moral anxiety in the reader as he deals with the subject of spying and reporting, which he sees as a disaster, though in a measured style. He does not portray spies and informants directly as objects 
of and hatred and resentment. However, situations that might cause serious discomfort in people are presented as gently as possible, which is a kind of self-censorship applied by the author. Güntekin does not apply a statist approach when addressing the above issues but identifies the root of the problem and points out the remedies. He draws attention to the aspects of spying that negatively affect many segments of society, large and small. Thus, the identity of investigators does not fall within the limits of his interest. Rather than targeting individuals, he critiques their mentality. Accordingly, when an environmentof fear, which feeds a mentality in which people are accused and slandered on absurd grounds, is extinguished through reason and science, such inhuman activities will wither away. Handling his novels in a realistic way, Güntekin filters through every period he lived in and writes with a sense of responsibility. For example, he does not refrain from criticizing a group that he otherwise portrays as a supporter of freedom and justice. Moreover, his heroes, who are supporters of this group, commit similar injustices when they assume political power, and he has them deported for this reason. The author's implicit aim is to prevent the reader from blessing a given administration or party by creating an awareness of humane administration.

Conversely, Güntekin shows the long-term effects of political events on people in his novels and enables the reader to think about the relevant period. For example: A boy of 17 or 18 who is exiled from school and deprived of education for years for reading a book that the government did not approve of; the exile of a doctor and his death in misery overseas for questioning the country's course; reporting on and removing the epaulettes of a soldier playing traditional game without question. All of this material permits the reader to make inferences about the political environment. Güntekin was a master novelist. While he creates a deeply felt atmosphere of fire and political reality, he nonetheless tolerates every period and person, expands his sphere of influence day by day with his unique style and point of view, and attracts attention. 


\section{Giriş}

Arapçadan Türkçeye geçmiş bir sözcük olan hafiye, "gizli işleri yürütmekle görevli memur, casus", "gizli polis", anlamına gelirken bu kelimeyle bağlantılı olan ve Fransızcadan Türkçeye giren jurnal (journal) ise biri hakkında yetkililere yapılan ihbar, iletilen kötüleme yazısı, "ispiyon"33 anlamlarında kullanılır. Osmanlının ıslahatçı padişahlarından II. Mahmut (1808-1839), politikaları hakkındaki düşüncelerini, halkın istek ve şikâyetlerini öğrenmek amacıyla devletin dört bir yanından jurnal toplama teşebbüsünde bulunur. Bilgi akışının sağlıklı yürümesi ve jurnalin sistemli hâle gelmesi için bir buyruk yayınlatır. Bu buyrukta şehir merkezleri, kaza ve kasabaların yöneticilerinin bir jurnal kâtibi atayacağı, halkın refah ve huzurunu ilgilendiren iyi kötü her konu hakkında bilgi toplanacağı ve atanan kâtiplerin bu jurnalleri İstanbul'a ulaştırmakla görevli oldukları yazılıdır. ${ }^{4}$ II. Mahmut'un geniş coğrafyaya sahip bir imparatorluğu denetlemek amaciyla valilerden sade vatandaşa kadar her kesim hakkında bilgi toplaması, bir zaruret olarak görülür. Ancak başlangıçta idarî sistemin işleyişini kolaylaştırmak için tesis edilen hafiyelik faaliyetleri, ilerleyen dönemlerde saray ve çevresinde cereyan eden güç savaşlarının üstü örtülü, gizli bir enstrümanı/aracı hâline gelir. Íktidar mücadelesi ${ }^{5}$ için hafiyeler tayin edildiği gibi sıradan vatandaşlara yönelik takip, gözetleme, espiyonaj ve raporlama gibi çalışmalar yapılmaya başlanır.

İstanbul'un herhangi bir mahallesindeki berber dükkânında devletle ilgili sohbet yapıldığ 1 gerekçe gösterilerek dükkânın mühürlenmesi, dükkân sahibi ile bu sohbeti yapanların cezalandırılması gibi örnekler, sıradan vatandaşlar hakkında istihbarat toplandığını ortaya koyar. ${ }^{6}$ 1840-1845 yıllarına ait Osmanlı Arşivleri incelendiğinde bu dönemi içeren ve "havadis jurnalleri" adını taşıyan seri belgeler bulunur. Yüzlerce sayfa bilgiyi ihtiva eden bu belgelerde o dönemin sade İstanbul vatandaşının çarşıda, pazarda, kahvehanede, sokakta veya evlerinde yaptıkları sohbetlere kulak kabartan hafiyelerin jurnalleri kaydedilmiştir. Söz konusu raporlarda sohbetlerin

1 İsmail Parlatır, Osmanlı Türkçesi Sözlüğü, (Ankara: Yargı Yayınevi, 2010), 555.

2 Ferit Devellioğlu, Osmanlıca-Türkçe Ansiklopedik Lûgat, (Ankara: Aydın Kitabevi Yayınları, 1993 ), 311.

3 Parlatır, Osmanlı Türkçesi Sözlüğ̈̈, 806.

4 Orhan Koloğlu, Jurnal, Osmanlı Ansiklopedisi (Tarih, Medeniyet, Kültür), 7, (İstanbul: İz Yayınları, 1996$), 60$.

5 Ahmet Cevdet Paşa, devlet şurası başkan yardımcılığı görevinde iken bu görevi iptal edilerek isteği dışındaYanya şehrine tayin edilir. Cevdet Paşa, bu dönemde Mecelle'nin onuncu kitabını yayımlamış, on birinci ve on ikinci kitaplarını da basmak üzeredir. Yanya şehri de ailesini yanında götüremeyeceği bir yerdir. Çocuklarıyla beraber gidebileceği bir şehre gönderilme talebiyle tayininden sorumlu Avni Paşa'nın yanına gider. Avni Paşa'nın Cevdet Paşa hakkında onun gıyabında dahi kötü söz söylemediği bilinmesine rağmen İstanbul'dan gönderilmesinin nedenini anlayamaz. Ancak bir zaman sonra Avni Paşa'nın Sultan Abdülaziz'i tahttan indirme planları yaptığını, Cevdet Paşa'ya da tam olarak güvenmediği için onu Yanya'ya üç ay süreyle geçici olarak tayin ettiğini yine kendisinden öğrenir. Yine o dönemlerde Avni Paşa’nın yakınlarından Zaptiye Nazırı Hüsnü Paşa, Cevdet Paşa'nın tüm hareketlerini izlemeleri için hafiyeler görevlendirmiştir. Hatta bunların arasında Cevdet Paşa'nın iyilik ve ihsanda bulunduğu bir kişi dahi vardır. Zamanında Cevdet Paşa'dan iyilik görmüş olan bu kişi, Paşa'ya kendisiyle beraber başka hafiyelerin de takibi altında olduğunu gizlice söyler. Ahmet Cevdet Paşa, Tezâkir, Haz. Cavid Baysun, II. Seri, (Ankara: Türk Tarih Kurumu Basımevi, 1967), 131-132.

6 Mehmet Ali Beyhan, Câbî Tarihi, (İstanbul Üniversitesi Sosyal Bilimler Enstitüsü Yayımlanmamış Doktora Tezi, 1992), 284; Mehmet Ali Beyhan, "II. Abdülhamid Döneminde Hafiyye Teşkilatı ve Jurnaller", İlmî Araştırmalar, $8,(1999), 67$. 
yapıldığı yer, sohbeti yapan kişiler ayrıntılı bir şekilde verilmiştir. Genel referans içeren raporlar sınırlıdır. Onun yerine Osmanlı yöneticilerinin "devlet sohbeti” olarak tanımladıkları siyâsî konuşmaları kimin nerede, hangi ayda, hangi saatte yaptığı, sözü söyleyenin mesleği, unvânı, evli veya bekâr olduğu, nerede ikamet ettiği gibi hemen her yönüyle tüm ayrıntılar incelikle not edilmiştir. Hafiyelerin gerçekte kim olduğuna yönelik elde kesin bilgiler olmamakla birlikte raporlarda hafiyelerin sohbetlerini kaydettikleri kişilerle yakın arkadaş ya da tanıdık olduklarına dair yüzlerce örnek bulunur. ${ }^{7}$ Hatta oluşan jurnalcilik ortamı "babanın evlâdına", “evlâdın babasına", "kardeşin kardeşe", "kocanın karısına" hiçbir güveninin kalmaması ${ }^{8}$ sonucunu doğurur. Bu da hafiyeliğin ulaştığı dramatik boyutu gösterir.

Hafiye teşkilatının temelleri II. Abdülhamid'den önce atılsa da jurnal, Abdülhamid Dönemi'nde bir "tarih terimi"’ kimliği kazanır. Osmanlı tarihinde jurnalcilik, "Abdülhamid saltanatının ve hükümetinin ikinci yarısını en iyi teşhis ettirecek bir tabir"10 olarak ifade edilir. İmparatorluğun zayıfladığı bir dönemde amcası Abdülaziz 'in şüpheli ölümü ${ }^{11}$ sonucu yerine geçen V. Murâd da kısa süre içinde tahttan indirilmesiyle Abdülhamid, Osmanlı İmparatorluğu'nun en çalkantılı dönemi olan 1876 yılında tahta oturur. Kendinden önceki padişahların yaşadıkları, Abdülhamid'in korkuyla hareket etmesine neden olur. Güvenliğini tehlikede gören, şüphe ve korkularla hareket eden Abdülhamid'in insanlara itimatsızlığg, "onun devrini bir 'korku saltanatı' hâline getiren en kuvvetli sebeplerden biri[dir]"12. Abdülhamid, devleti 1909 yılına kadar otuz yılı aşkın bir süre Yıldız Sarayı'ndan mutlak otoriteyle yönetir. İstibdâd döneminde korku ve şüphe her yerde hissedilir. İç ve dış siyasetin tayin edildiği Yıldız Sarayı, "kökleri toplumun en ücra köşesine kadar nüfûz etmiş bir kartal yuvası görünümüne bürün[ür]”. ${ }^{13}$ Abdülhamid, bu sarayda saltanatı boyunca sürekli değişen asker ve sivillerden oluşan bir grupla

7 Cengiz Kırlı, “Kahvehaneler ve Hafiyeler: 19. Yüzyıl Ortalarında Osmanlı'da Sosyal Kontrol”, Toplum ve Bilim, $83,(2000), 58-62$.

8 İbnülemin Mahmut Kemal İnal, Son Sadrazamlar, 3, 3. Baskı, (İstanbul: Dergâh Yayınları, 1987), 1277; Basîretçi Ali Efendi, İstanbul'da Elli Yıllık Önemli Olaylar, (İstanbul'da Yarım Asırlık Vekayi-i Mühimme, 1325), (İstanbul: Sander Yayınları, 1976), 101; Yavuz Selim Karakışla, "II. Abdülhamid'in İstibdat Döneminde Jurnalciliğin Boyutları", Toplumsal Tarih, 120, (2003a), 27.

9 Beyhan, "II. Abdülhamid Döneminde Hafiyye Teşkilatı ve Jurnaller”, 68.

10 Süleyman Kâni İrtem, Abdülhamid Devrinde Hafiyelik ve Sansür, Haz. Osman Selim Kocahanoğlu, (İstanbul: Temel Yayınları, 1999), 5.

11 Damad Nuri Paşa, Damad Mahmud Paşa, Midhat Paşa gibi devlet adamları ile Mabeynci Fahri Bey, Mabeynci Seyyid Bey, Binbaşı Necip Bey, Pehlivan Mustafa Çavuş gibi asker ve sivil şahısların bulunduğu on bir kişi, Abdülaziz'i öldürmekle itham edilir ve mahkemeye sevkedilirler. İ. Hakkı Uzunçarşıll, Midhat Paşa ve Yıldız Mahkemesi, (Ankara: Türk Tarih Kurumu Basımevi, 2000), 223-224; Ardından Midhat Paşa, 1881 yılında Abdülaziz'in öldürülmesine iştirak suçlamasıyla Yıldız Sarayı'nda kurulan özel bir mahkemede yargılanır. Midhat Paşa muhaliflerinden oluşan mahkeme heyeti, Midhat Paşa'nın aksi yöndeki savunmasına rağmen onu suçlu bulur ve Paşa'ya idam cezası verir. İçten ve dıştan gelen itirazlar üzerine Abdülhamid, Midhat Paşa'nın idam cezasını, ömür boyu hapse çevirir ve Taif’e sürgün eder. Ailesinden aktarılan bilgilere göre sürgün döneminde tasavvufa yönelen Midhat Paşa, 1884 yılında boğularak öldürülür. Gökhan Çetinsaya, Ş. Tufan Buzpınar, "Midhat Paşa”, İslâm Ansiklopedisi, 30, (İstanbul: Türkiye Diyanet Vakfı Yayınları, 2005), 9-10.

12 İrtem, Abdülhamid Devrinde Hafiyelik ve Sansür, 6.

13 Yavuz Selim Karakışla, "Sultan II. Abdülhamid'in İstibdat Döneminde (1876-1909) Hafiyelik ve Jurnalcilik", Toplumsal Tarih, 119, (2003b), 12. 
çalışır. Padişahın yakın çevresini oluşturan bu görevliler takımı, II. Meşrutiyet kaynaklarında "kurenâ", "kamarilla” veya "saray takımı” olarak geçer. Bunların arasında "Ser-hafiye” unvânlı ve jurnalle uğraşan kişiler yer alır. ${ }^{14}$ Abdülhamid Dönemi’nde hafiyelik, gizli polislikten farklı olarak yürütülür. Mîzâncı Murâd, devletin emniyet ve güvenliği için çalışan gizli polisliğin gerekliliğine vurgu yaparken öte yandan Abdülhamid Dönemi hafiyeciliğini toplumun ahlâkını bozan, bir kişiyi memnun etmek amacıyla hareket eden, tasvip edilemez bir yapılanma olarak tanımlar. ${ }^{15}$ Abdülhamid de jurnalciliğin kötü bir şey olduğunun farkındadır ancak bundan vazgeçmenin mümkün olmadığı düşüncesindedir. Ona göre devlette hilekârlık, entrikacılık büyük boyutlara ulaşmıştır. Devleti kendilerinin kurtaracağına inanan, kendi işiyle uğraşmayan memur ve subaylar entrika çevirerek padişaha hakaretten ve iftiradan çekinmezler. Abdülhamid, bu gerekçelere dayanarak devlet yönetiminde sert politika izler. ${ }^{16}$ Abdülhamid'in kendisine kul köle insanları iktidar makamlarına getirmek suretiyle oluşturduğu hafiye teşkilatı; tüm memleketi korku ve endişe içinde kıvrandıran, konuşmamaya dahası düşünmemeye zorunlu kılan bir kuvvet hâlini alır. ${ }^{17}$ Memlekette korku havasına neden olan şey; halkın yersiz korkuları, sanrıları değildir. Padişahın kendi korkularının düzenli olarak bir şekilde halka aktarılmasıdır. Abdülhamid'in vehimlerini ülkenin en ücra köşesine kadar yansıtması, "imparatorluk nüfusunu bir tür 'kollektif paranoya' içerisine sürüklediğini göster[ir].”18

Saraydan başlayan sıkı kontrol sistemi, ülkenin sınırlarını da aşar. Hafiyelik kimi insanların mesleği iken küçük büyük pek çok memurun makam, nişan ve hediye elde etmelerini sağlayan bir basamak olarak da yaygınlaşır. Abdülhamid'in kendini yalnız ve güvensiz hissettiği ruhsal durumundan yararlanmaya ve bu durumu tahrik edip kullanmaya çalışanlar, jurnalleri padişaha sadık olduklarını kanıtlamak, rütbe elde etmek veya padişaha kendilerini hatırlatmak için bir firsat olarak görür. Resmi görevi olanların haricinde gerçek dışı, uydurulmuş, asılsız jurnalleri yazanlarla karşılığında belli şeyler beklentisiyle hareket eden kişiler eklendiğinde hafiyelik, bir güvenlik teşkilatı görünümünden uzaklaşır. Hafiye teşkilatının bir kolunu sarayın ileri gelenleri oluştururken diğer kolları en alt tabakadaki sıradan insanlara kadar uzanır. Belli bölümlere ve gruplara ayrılan hafiye teşkilatının liderleri de birbirleriyle rekabet içerisindedir. Bu kişiler, karşılarındakini kötüledikçe saraya daha sadık görünürler ve daha büyük "lütuflara"19

14 Emre Gör, "II. Abdülhamid Dönemi'nden Bir İstihbaratçı Profili: Serhafiye Fehim Paşa (1873-1908)", Stratejik ve Sosyal Araşttrmalar Dergisi, 3/1, (2019), 72.

15 Mehmed Murâd, Müdâfaa Niyetine Bir Tecâvüz! (Kırk Anbar'a Cevâb), (Paris: Meşveret Matbaası, 1314), 11.

16 Cevdet Küçük, "II. Abdülhamid", İslâm Ansiklopedisi, 1, (İstanbul: Türkiye Diyanet Vakfı Yayınları, 1988), 219.

17 Mehmet Kaplan, Tevfik Fikret, (İstanbul: Dergâh Yayınları, 1998), 34.

18 Yavuz Selim Karakışla, "II. Abdülhamid'in İstibdat Döneminde Jurnalciliğin Boyutları", Toplumsal Tarih, 120, (2003a), 24.

19 Tahsin Paşa hatıralarında Abdülhamid'in kendi siyasetini başarılı kılmak için memleketi sıkı bir kontrol çemberi içine aldığını, bunun için de sarayın kapısından başlamak üzere memleketin her yerinde güçlü bir istihbarat şebekesi oluşturduğunu ve bu şebeke çalışanlarına da pek çok ihsanlarda bulunduğunu belirtir. Tahsin Paşa, Abdülhamid ve Ylldiz Hattraları, (İstanbul: Milliyet Matbaası, 1931), 11-12. 
kavuşurlar. ${ }^{20}$ Devletin her kademesinde bulunan kişilerin isimsiz bir jurnal ile saraya şikâyet edilebildiği yapılan çalışmalarda görülür. Örneğin Sivas Valisi Halil Rıfat Paşa ile Sivas Merkez Mutasarrıfı Selim Sırrı Paşa hakkında çeşitli suçlamaların yapıldığı bir ihbârnâme doğrudan saraya gönderilir. İhbarnamenin konusu, Halil Rıfat Paşa'nın özel hayatı ve yaşadığı gayrı meşru ilişkilerdir. İhbarname; Halil Rıfat Paşa'nın köçek oynattığı, on yedi on sekiz yaşlarında bir kızı istismar ettiği, bu nedenle evlenmek zorunda kaldığı ancak bir ay sonra bu kızı bıraktığı, rüşvet aldığı, adam kayırdığı şeklindeki suçlamaları içerir. Bu işleri de Selim Sırrı Paşa ile ortak hareket ederek yaptığı belirtilir. İsimsiz bir jurnal olmasına rağmen Abdülhamid bu konuda bir soruşturma açtırır. Yapılan soruşturmada bilgisine başvurulan bir kişinin verdiği ifade sonucunda Halil Rıfat Paşa suçlu bulunmazken Sivas Merkez Mutasarrıfı Selim Sırrı Paşa'nın suçlu olduğu tespit edilir. Selim Sırrı Paşa mutasarrıflık görevinden 16 Aralık 1883 tarihinde alınır. ${ }^{21}$

1890-1895 yılları arası, Abdülhamid yönetimi açısından bir dönüm noktası olur. Abdülhamid, fikirlerine değer verdiği Ahmet Cevdet Paşa gibi devlet adamlarının 1890 yılına kadar olan süreçteki vefâtları üzerine bu kişilerin yerlerine gelen Mahmut Şevket, İbrahim Hakkı, Hüseyin Hilmi Paşa gibi II. Meşrutiyet Dönemi'nde de görev ve kariyerlerini devam ettiren askerî ve sivil bürokrasiyle çalışmaya başlar. Mahmut Nedim Paşa'nın Abdülhamid'in etrafını çevrelemesi, Mabeyn yazı işlerinin iş yoğunluğu ile personel sayısındaki artış, şeyhülislama yahut sadrazama ait olan Abdülhamid'le doğrudan yazışma imtiyazının pek çok makama da sağlanması, Yıldız Sarayının ve Mabeynin merkezi bir konuma geldiği argümanını teyit eder. Yönetime karşı siyâsî muhalefet, özellikle 1890'ların ortalarından itibaren görülmeye başlanır. Öğrenciler, gazeteciler, aydınlar, bürokraside görev yapanlar, tarikat şeyhleri ve âlimlerin de yer aldığı pek çok muhalif bu dönemde ortaya çıkar. Bu ve benzeri durumlar, Abdülhamid'in giderek otoriterleşmesine, baskı, jurnal, "sürgün"22 gibi uygulamaların artmasına yol açar. ${ }^{23}$ Bu dönemde karşılaşılan aksaklıklardan biri de sansürdür. Sansür komitesinin uygulamaları,

20 İlknur P. Haydaroğlu, "II. Abdülhamit'in Hafiye Teşkilatı Hakkında Bir Risale”, Ankara Üniversitesi DTCF Tarih Araştırmaları Dergisi, 17/28, (1995), 109-110.

21 Mehmet Mercan, "II. Abdülhamit Dönemine Ait Bir Jurnal Örneği: Sivas Valisi Halil Rıfat Paşa Hakkında Bir İhbârnâme”, Fırat Üniversitesi Sosyal Bilimler Dergisi, 17/2, (2007), 344-350; Başbakanlık Osmanlı Arşivi İrade Dahiliyye nr. 71819.

22 Anadolu şehirlerinin ya da Yakındoğu'daki Arap şehirlerinin yanında Ege ve Akdeniz sahilleri boyunca yer alan Midilli, Sakız, Rodos adaları sürgün yerleri listelerinde bulunur. Bu yerlerin hâricinde Arabistan, Yemen ve Trablusgarp da vardır. Trablusgarp, uzak ve zor ulaşılır olması yönüyle iktidar açısından ideal bir sürgün yeridir. Trablusgarp'a sürülenler, göz hapsinde tutularak okulda, idari büroda veya mahkeme gibi çeşitli yerlerde çalıştırılabilirken en tehlikeli görülen muhalifler, Fizan'daki Marzuk kalesine hapsedilebilir. François Georgeon, Sultan Abdülhamid, çev. Ali Berktay, (İstanbul: İletişim Yayınları, 2012), 217.

23 Gökhan Çetinsaya, "II. Abdülhamid'in İç Politikası: Bir Dönemlendirme Denemesi”, Osmanlı Araştırmaları, The Journal of Ottoman Studies, XLVII, (2016), 387-391; 1847 y1lında çıkan ilk devlet salnamesinde mabeyn görevlileri toplam 43 kişi iken II. Abdülhamid Dönemi’nde mabeyn görevlilerinin sayısı artırılarak 424 kişiye ulaşır. Mabeyn ve buradaki kişilerin işlevleri hakkında ayrıca bkz. Ali Akyıldız, II. Abdülhamid'in Çalışma Sistemi, Yönetim Anlayışı ve Babıali’yle (Hükümet) İlişkileri, Osmanll, III, (Ankara: Yeni Türkiye Yayınları, 1999), 286-297; Ali Akyıldız, “Mabeyn-i Hümâyun”, İslâm Ansiklopedisi, 27, (İstanbul: Türkiye Diyanet Vakfi Yayınları, 2003), 283-286. 
padişahı dahi kızdıracak noktaya ulaşır. Dışarıda ve içeride Türk basınına karşı uygulanan kısitlamalar, engellemeler İmparatorluğun sosyal bilimlerde yerinde saymasına neden olur. Gençler, politik anlayış açısından dünyanın gerisinde kalır. Denetimlerin yüksek seviyede olduğu hatta aydınların boğulduğu İstanbul'da ortaoyunundan Karagöz'e kadar seyirlik oyunlarda dahi sansür uygulanır. ${ }^{24}$

Kanûn-1 Esâsî’nin yeniden yürürlüğe girmesiyle İttihat ve Terakkî Cemiyeti, Osmanlı Devleti ile halkın arasında yanlış anlaşılmalara neden olan hafiyeliğin kaldırılması talebinde bulunur. Bu talep üzerine hafiyeliğin Meclis-i Vükelâ tarafından kaldırıldığı 24 Temmuz 1908 tarihinde basın yoluyla ilan edilir. ${ }^{25}$ Abdülhamid de Meclis-i Vükelâ'nın aldığı kararı geldiği şekliyle 31 Temmuz 1908 tarihinde onaylar. ${ }^{26}$

II. Abdülhamid'in 27 Nisan 1909 tarihinde tahttan indirilmesinin ardından jurnaller, Y1ldız Sarayından alınır, Harbiye Nezaretinde bulunan bir köşke getirilir. Jurnalleri tasnif etmek için bir komisyon kurulur. Komisyon üyeleri bir grup milletvekili ve askerlerden oluşur. Jurnaller, önem sırasına göre tasnif edilip katalog şeklinde hazırlanırken komisyonun çalışmaları zamanla yavaşlar. İttihat ve Terakkî’nin yönetimdeki etkisinin sona ermesiyle komisyon dağıtılır ve jurnaller yakılır. Jurnaller yakıldığında komisyonda görev yapan Asaf Tugay, İbret isimli eserinde kimi hafiyelerin isimleri ile jurnal özetlerini içeren küçük bir defteri kendisine sakladığını belirtir. ${ }^{27}$ Saklanılan defterlerle ya da halk arasında anlatılanlarla her biri ayrı bir hikâyeyi barındıran söz konusu jurnaller, tarihî bir gerçeklik olarak romanlara da malzeme olurlar. Reşat Nuri Güntekin'in romanları da Meşrutiyet'in İlânından Cumhuriyet'in İlânına kadar pek çok tarihsel arka planı içerir. Bu manâda istibdâd dönemine damgasını vuran hafiyelik ve jurnal, Güntekin'in romanlarında güçlü bir gözlemle ve "realist" 28 bir çizgide işlenir. Ancak Güntekin hafiyeliğin zirvede olduğu siyâsî dönemde herhangi bir edebî faaliyet yürütmez. Nitekim "Abdülhamid zamanında edebiyatla uğraşmak cesaretini haklı olarak kendisinde bulamayan yazarın, 1908' den sonra [romanlarını] yayımlamaya başla[dığ1]”229 görülür. Yazarlık serüveni, ülkede pek çok siyâsî döneme denk gelen Güntekin; zamanı iyi okuyan bir yazar olarak romanlarında ülkenin içinde bulunduğu sorunları, çözüm önerileriyle birlikte ele alır. Eserlerinde ana konunun yanında tâlî pek çok konuyu işler. Eserlerine serpiştirdiği hafiyelik ve hafiyelikle birlikte ortaya çıkan uygulamalar, bu tâlî konulardan biridir. Sözü edilen konunun

24 https:/www.hurriyet.com.tr/yazarlar/ilber-ortayli/2-abdulhamidi-gercekten-taniyor-muyuz-40230875 24.09.2016 tarihli yazısı (Son Erişim 31.07.2021)

25 Arşiv Belgelerine Göre Osmanlı'da İstihbarat, T.C. Başbakanlık Devlet Arşivleri Genel Müdürlüğü, Osmanlı Arşivi Daire Başkanlığı, Yay. Nu: 148, (İstanbul: Seçil Ofset, 2017), 361.

26 Emrullah Tekin, "Hafiye", İslâm Ansiklopedisi, 15, (İstanbul: Türkiye Diyanet Vakfı Yayınları, 1997$), 116$.

27 Haydaroğlu, "II. Abdülhamit'in Hafiye Teşkilatı Hakkında Bir Risale”, 110; Asaf Tugay, İbret, (İstanbul: Sucuoğlu Matbaas1, 1961), 17.

28 Realist yazar; insanı ve toplumu tüm yönleriyle irdeler. İyi kötü, güzel çirkin hemen her şeyi tasvir eder. Kişilikleri belirleyecek derecede ayrıntılı tasvirler yapar. Kişi ve olaylar karşısında bir tercihte bulunmadan veya yargılamadan hareket eder. Gözlemlerini belgelere ya da beyanlara dayandırmaya çalışır. Nurullah Çetin, Roman Çözümleme Yöntemi, (Ankara: Öncü Basımevi, 2004), 79.

29 Kenan Akyüz, Modern Türk Edebiyatının Ana Çizgileri, (İstanbul: İnkılâp Kitabevi, 1995), 189. 
kapısı aralandığında ise istibdâdî yönetimin araçları olan yasaklar, sansür, hafiyelik, jurnal, sürgün ve tevkiflerin olduğu görülür.

\section{Sansür ve Yasaklı Kitaplar}

Maarif Nezareti'nden ruhsatnâme alınmadan yayımlanan eserler, izinsiz basılan kitaplar sınıfına girer. Devletin görevlendirdiği memurlar tarafından yapılan aramalarda ruhsatsız, tehlikeli veya yasak oldukları gerekçe gösterilerek matbaalardaki, kitapçılardaki kitaplara el konulur. ${ }^{30} 1900$ yılında Matbaa-1 Osmânî’de basılan katalogdaki listelerde ${ }^{31}$ Türkçe, Arapça, Almanca, İtalyanca, Fransızca gibi dillerde kitaplar ve yazarlarının isimleri bulunur. Bu katalogda Nâmık Kemâl'in, Celâleddin Harzemşâh, Vatan yahut Silistre, Zavallı Çocuk, Cezmî, "Evrâk-ı Perîşân”’32; Ahmet Mithat Efendi’nin Arnavutlar, Solyotlar ve Süleymân Musûlî; Abdülhak Hâmit Tarhan'ın Eşber, Tezer, Makber, Içli Kız, Sahrâ, Nazife, Hacle; Mizancı Murat'in Akıldan Belâ, Târih-i Kırk Vezîr, Tarih-i Umûmî; Tunalı Hilmi'nin Birinci Hutbe ve İkinci Hutbe; Ahmet Vefik Paşa'nın Fezleke-i Târih-i Osmânî; Ziya Paşa'nın Endülüs Tarihi; Cevdet Paşa'nın Kısas-ı Enbiyâ ile Voltaire, J. J. Rausseau, Machiavel, Racine, Victor Hugo,

30 Fatmagül Demirel, Raşit Çavaş, "II. Abdülhamid Dönemi’nde Gümrüklerde El Konulan (Ve Elbette Yakılan) Kitaplar”, Müteferrika, 26, (2004), 152; Fatmagül Demirel, II. Abdülhamid Döneminde Sansür, (İstanbul: Bağlam Yayınc1lik, 2007), 96-97.

31 Memâlik-i Mahrûsa-i Şâhâneye Duhûl ve Intişârı Memnû Bulunan Kütüb ve Risâil-i Muzırrânın Esâmîsini Mübeyyin Cedveldir, Matbaa-i Osmânîye, 1900, İ.B.B. Atatürk Kitaplığı; Çağrı Çalışkan, II. Abdülhamid Döneminde Kitaplar Üzerinde Sansür Uygulamalarl (1876-1909), (Yüksek Lisans Tezi, Pamukkale Üniversitesi Sosyal Bilimler Enstitüsü, 2019), 4.

32 Nâmık Kemâl; tarih, politika gibi konulardan başlayarak tercümelerini, mektuplarını, manzum ve mensur eserlerini bir sıra gözetmeksizin Evrâk-ı Perişân isimli bir kitap serisi içinde yayımlama kararı alır. Yayımlamak için adım attığı 1872 yılında külliyât için uğraşır. Ancak mücadeleyle geçen yaşamı, eserlerini toplama hayalini sekteye uğratır ve bu seriden yalnızca üç kitabı çıkarma imkânı elde eder. Serinin ilk kitabından sonra 1873 yılında ikinci ve üçüncü bölümleri de basılır. Serinin ilk kısmı Selahaddin Eyyûbiye, ikinci kısmı Fatih'e, üçüncü kısmı ise Selim'e tahsis edilmiştir. Yavuz Sultan Selim’e ayrılan bölümün çıkışının ardından hükümet, daha öncesinde pek fazla uymadığı 1857 yılında oluşturulmuş “Matbaa Nizamnâmesi”nin hükmü ortadan kalkmış 3. maddesine dayanarak Evrâk-ı Perişân'ın yayımlanmasına müdahale eder. Nâmık Kemâl’in siyâsi şahsiyeti ve yazılarının toplumda oluşturduğu etki, onun yalnızca yazılarına değil yayımlayacağı kitaplara karşı da hükümeti tedbir almaya sevkeder. Selim'in yayımlanmasından üç ay sonra Vatan yahut Silistre oyunu oynanır ve bu oyunun ardından Nâmık Kemâl Kıbrıs'a sürgün edilir. Bu nedenle külliyât çalışması yarıda kalır ve Nâmık Kemâl, bir daha bu çalışmaya dönemez. Hükümet tedbirine hedef olan Evrâk-ı Perişân, bir yayım mücadelesinin merkezi hâline dönüşür. Hükümet, Evrâk-Perişân'dan hareketle kitap yayımını zorlaştırmaya çalışır ve kitapların Meclis-i Maarif’ten izinsiz bastırılmasının önlenmesi için tedbir alır. Nâmık Kemâl, bir yayım mücadelesine girişir ve hükümetin bu baskısına karşı basım tarihinin en şiddetli ve çetin ilk mücadelesi başlar. Ömer Faruk Akün, "Nâmık Kemâl'in Kitap Halindeki Eserlerinin İlk Neşirleri”, Türkiyat Mecmuası, 18, (1976), 11-13; Meclis-i Maarif’ten izin alınmadan basıldığg gerekçe gösterilerek Evrâk-ı Perişân toplatılır. Bunun bir bahane olduğuna değinen Tanpınar, toplatılmanın ardında başka bir neden olduğunu belirtir. EvrâkPerişân'da Nâmık Kemâl'in yazdığı eserler, "iki şanlı dedesi” (Fatih Sultan Mehmed ve Yavuz Sultan Selim) içindir. Bu padişahlardan biri, Belgrad hariç Sırbistan'1 vatan toprağına katmış, diğeri ise Mısır'1 fethetmiştir. Nâmık Kemâl'in ecdâdı bu eser vasıtasıyla anması, Sultan Abdülaziz'in Avrupa'nın 1srarı neticesinde Sırbistan kalelerini Sırplara teslim ettiği gerçeğini bir şekilde hatırlatmış olur. Dahası o dönemde Mısır da açıkça elden çıkmak üzeredir. Tanpınar, bunların bir yorumlama olduğunu ayrıca belirtse de ona göre kesin olan husus, Evrâk-ı Perşân'ın yayımlanmasının sarayı ve hükümeti ürküttüğ̈̈ür. Ahmet Hamdi Tanpınar, On Dokuzuncu Asır Türk Edebiyatı Tarihi, Haz. Abdullah Uçman, (İstanbul: Dergâh Yayınları, 2013), 353. 
Jules Verne gibi yerli-yabancı yazarların kitapları yasaklı kitaplar olarak gösterilir. ${ }^{33}$ Yasaklı kitaplar, yakılmak üzere Maarif Nezareti’ne gönderilir. 1902 yılının Mayıs ayında Çemberlitaş Hamamı’nda “'yakılan kitaplar”34, 29.681adettir. Bu sayıya Maarif Nazırı'nın 24 Mayıs 1902 tarihli yazısının ekinde bildirdiği kitaplar dâhil edildiğinde sayı, 30.302'ye çıkar. ${ }^{35}$

Reşat Nuri'nin romanlarında eserleri yasaklanan hatta yakılan bir sanatçı olan Nâmık Kemâl, ekseriyetle Abdülhamid'in karşısında yer alan kişilerin kahramanı olarak tanıtılır. Meşrutiyet yanlıları onun romanlarını, şiirlerini, tiyatro eserlerini okur. Bu eserler nedeniyle sürgün edilseler de bu kişiler için Nâmık Kemâl'in eserleri, bir başucu kitabıdır.

Meşrutiyet döneminde geçen olayların anlatıldığı Damga romanında; İffet, saraya sadık bir paşanın oğludur. Ancak aile ve yakın çevresinin saraya olan bağlılığının aksine İffet, "saray adamı olmaktan iğren[ir]" (s. 21). Arkadaşı Celal, İffet'in bir paşanın oğlu olduğunu bilmesine rağmen ona hürriyetten, meşrutiyetten, padişahın yaptığı haksızlıklardan, hafiyelerin kötülüklerinden bahseder. Meşrutiyeti savunan Celal, "Nâmık Kemâl'in şiirlerini oku[r]" (s. 21). Celal'den başka İffet'in okul çevresinde onu etkileyen ve ona bazı fikirler veren kişiler de vardır. Bunlardan biri de İffet'in serbest fikirli lise hocası Vecdi Bey'dir. Vecdi Bey hakkında saraya kim tarafından gönderildiği belli olmayan bir jurnal yazılır. Jurnalde "[Vecdi Bey’in] mefsedetkârane telkinlerde bulun[duğu], melek-haslet padişahımız aleyhine bazı kâfir-i nimet hainler tarafından yazılmış yazıları oku[duğu]" (s. 23) bildirilir. Söz konusu ifadeler, saray tarafından soruşturma gerekçesi yapılır. Yapılan soruşturmada “[Vecdi Bey’in] Meşrutiyet’ten, Kanûn-1 Esâsî' den bahset[mesi]” (s. 24) de bir suç olarak gösterilir. Meşrutiyetten söz etmek veya onu yaymak, sarayın onaylamadığı kitapları okumak; hapsedilme, sürgün edilme nedenidir. Jurnalde geçen kâfir-i nimet hainlerin kimler olduğu romanda açıkça söylenmez ancak meşrutiyet yanlılarının saray karşıtı, Nâmık Kemâl'in şiirlerini ve yazılarını okuyanların ise meşrutiyet

33 Çağrı Çalışkan, II. Abdülhamid Döneminde Kitaplar Üzerinde Sansür Uygulamaları (1876-1909), (Pamukkale Üniversitesi Sosyal Bilimler Enstitüsü, Yüksek Lisans Tezi, 2019), 4.

34 Nâmık Kemâl'in Vatan yahut Silistre, Zavallı Çocuk, Intibah, Âkif Bey (Âkif Bey, bir tiyatro eseri olmasına rağmen listede Âkif Bey Hikâyesi şeklinde tanımlanmıştır), Osmanlı Tarihi, Evrâk-ı Perişân, Cezmi eserleri yakılan kitaplar listesinde yer alır. Demirel, II. Abdülhamid Döneminde Sansür, 173-178; Ayrıntılı liste için bkz. Fatma Demirel, Raşit Çavaş, "Yeni Bulunan Belgelerin Işığında II. Abdülhamid'in Yaktırdığı Kitapların Bir Listesi”, Müteferrika, 28, (2005) 3-23.

35 Demirel, II. Abdülhamid Döneminde Sansür, 101-104. 
yanlısı gösterilmesiyle "Nâmık Kemâl"36in "kâfir-i nimet hainlerden" olduğu sezdirilir. Gizli El romanında Aziz Paşa, devletten uzaklaştırılmış eski bir saray adamıdır. Meşrutiyet’ten sonra İttihatçılarla olan ilişkisini kesmiş, İstanbul'dan Gemlik'e yerleşmiştir. Paşa; okuyan, araştıran, açık görüşlü bir kişidir. Okullarda aşk şiirlerinin erkek öğrencilere dahi okutulmadığının söylendiği bir ortamda Paşa, "daha nelerden çekinilir o mekteplerde" (s. 40) diyerek okullarda kitapları sakıncalı görmenin yanlışlığını eleştirir ve kızı Seniha'ya Nâmık Kemâl'in "Cezmi” (s. 43) sini okutur.

36 Nâmık Kemâl, gençlik çağında hükümet tarafından hızlı bir şekilde "muzır bir ihtilâlci unsur" olarak algılanır. Oysa Nâmık Kemâl'in kitapları okunduğunda bu milletin kültürüne, inancına en küçük bir karşıtlık görülmez. Aksine yenilik taraftarı Nâmık Kemâl'in kitapları tarandığında onun tüm fikirlerinin İslam birliğinin sağlanması ve Osmanlı saltanatının devam ve temadisine uygun bir mahiyette olduğu görülür. $O$ dönemki hükümet bunu birdenbire anlayamaz. Ancak İbret gazetesinde çıkan yazıları ile Vatan yahut Silistre oyununda kullanılan halka yabancı olmayan ve bilinen sözleri, Nâmık Kemâl' in ifadelerinde bir "irade"ye dönüşmüştür. Türk millî ruhunun iradesini ortaya koyan, içten dışa doğru olan bu ifade şekli, Nâmık Kemâl'i ihtilâl unsuru olarak gösterir. Yahya Kemal Beyatlı, Eğil Dağlar, (İstanbul: İstanbul Fetih Cemiyeti Yahya Kemal Enstitüsü, 1975), 256-257; İbret Gazetesi, Vatan yahut Silistre'nin halkta uyandırdığı heyecan nedeniyle 3 Nisan 1873 tarihinde kapatılır ve yazarları da tutuklanır. İnci Enginün, Yeni Türk Edebiyatı Tanzimat 'tan Cumhuriyet'e (1839-1923), (İstanbul: Dergâh Yayınları, 2013), 62; Güllü Agob'un Gedikpaşa tiyatrosunda oynanan bu oyundan sonra halkın "Yaşasın millet! Yaşasın Kemal!" sözleri ile Sultan Abdülaziz'in yerine veliaht Murad'ın gelmesini isteyen halkın yine "Allah muradımızı versin” şeklindeki sözleri, Abdülaziz'i harekete geçiren saiklerden biri olur. Zira Nâmık Kemâl'in veliaht Murad ile bir münasebette olduğu da bilinen bir durumdur. Bu piyesin sonunda halkın yaptığı gösteriden saray istifade eder. İbret gazetesi kapatılır, yazarları tutuklanır ve ardından farklı yerlere sürgün edilirler. Nâmık Kemâl Magosa'ya, Ebuzziya Tevfik ile Ahmet Mithat Efendi Rodos Adası'na, Nuri Bey ile bir öğrenci olan İsmail Hakkı Efendi ise Akkâ'ya 10 Nisan 1873 tarihinde sürgüne gönderilir. Nâmık Kemâl vapura bindiğinde uzun bir süre halkın kendilerini kurtaracağı ümidi içindedir. Ancak kimse gelip onları kurtarmasa da o sürgündeyken piyesin, İstanbul'da hatta Abdülaziz' in huzurunda dahi birkaç defa oynandığını eklemek gerekir. Bu da eserin devrin ihtiyacına cevap verdiğini ortaya koyar. Ahmet Hamdi Tanpınar, Edebiyat Üzerine Makaleler, Haz. Zeynep Kerman, (İstanbul: Dergâh Yayınları, 1992), 226-227; Bizans İmparatorluğunun hâkimiyeti altında bulunan Rumeli toprakları, bir dönem Sırp tehdidi altındadır. Rumeli toprakları, Sırplar ve yabancı güçler tarafindan yağma ve tahribata uğramaktadır. Bizanslılar, bu tehlikelerden dolayı Orhan Bey'den yardım ister. Orhan Bey, Bizanslıları düşmanlardan korumak üzere Şehzâde Süleyman Paşa'yı görevlendirir. Süleyman Paşa, 1354 yılında Gelibolu kalesini fetheder. Bu fetih sonucunda Bizanslılar her yerden sıkışmış olur, Bizanslılar bu sefer de kendisine tehlikenin Osmanlı'dan geldiğini düşünerek eski düşmanı Sırplarla anlaşır. Ancak istediği sonucu elde edemez. Zira Süleyman Paşa Tekirdağ'a kadar olan yerleri de fethetmiştir. Süleyman Paşa, 1359 yılında bir av esnasında atının sendelemesiyle düşer ve ölür. "Rumeli Fatihi" olarak adlandırılan Süleyman Paşa'nın kabri Bolayır'da bir türbededir. Büyük düşünür ve şair Nâmık Kemâl, öldüğünde Süleyman Paşa'nın yanına gömülmeyi vasiyet eder. II. Abdülhamid de Şehzâde Süleyman Paşa'nın yanına bir kabir yaptırarak Nâmık Kemâl'in vasiyetini yerine getirir. Erol Güngör, Tarihte Türkler, (İstanbul: Ötüken Yayınları, 1995), 188-189. Nâmık Kemâl'in büyük değer verdiği bir şehzâdenin yanına öldüğü vakit gömülme isteğinin yerine getirilmesi, onun fikirlerinin zaman içerisinde hükümet tarafından anlaşıldığını gösteren bir durum olarak düşünülebilir. 


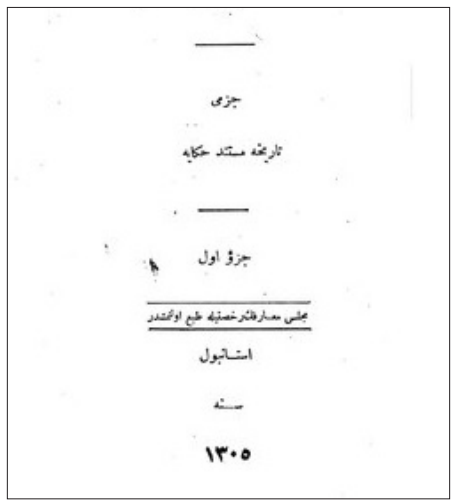

Cezmi $^{37}$

Gökyüzü romanının kahramanı, tıp tahsili görür. Mezun olduktan sonra doktor olup pek çok insanı ölümden kurtarmak, keşifler yapmak, üniversite okuduğu dönemde onun için ikinci derecede önem arz eder. Zira ona göre ülkenin idaresi bozuktur, hürriyet yoktur ve padişah insanlara zulmetmektedir. Ayrıca Batı’ya karşı da iki paralık itibarımız kalmıştır. Bu düşünceler, roman kahramanının gençlik dönemine ait olan ve serim bölümünde kısmen istihza ile anlatılan hatıralardır. Gemi azıya aldığı bu dönemde kahramanın, "Bu işleri ben düzeltmezsem kim düzeltecek?" şeklindeki düşüncesiyle ülkeyi kurtarmaya kendini adadığı belirtilir. "İstibdâd idaresine hizmet etmiş bir memurun, temiz, değerli bir insan olmasına imkân yoktur" (s. 12) denilerek istibdâd için çalışan insanların ahlâklı olmadığı düşüncesi işlenir. İstibdâda karşı olan üniversiteli gencin "Nâmık Kemâl'den Bibliotheque Socialiste'in küçük kırmızı propaganda kitaplarına kadar birçok yasak kitaplar” (s. 12) okuduğu ifade edilir.

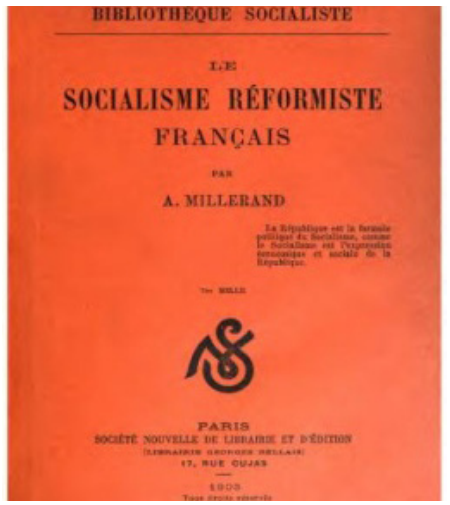

Bibliotheque Socialiste ${ }^{38}$

37 https://tr.wikipedia.org/wiki/Cezmi (Son Erişim: 18.07.2021)

38 https://archive.org/details/lesocialismeref02millgoog (Son Erişim: 07.07.2021) 
Yatılı okullarda okuyan öğrencilerin odalarında, dolaplarında, okul idaresi tarafindan yasaklı kitaplar arandığı, Bir Kadın Düşmanı romanında anlatılır. Romanda yatılı okul idaresi tarafından etüt odalarına baskınlar düzenlendiği, "talebenin çekmecelerinde yasak kitap[lar] ara[ndığı]" (s. 150) sakıncalı görülen kitapları bulunduranların tutuklandığı bir mektup sayesinde anlaşılır. Okuldaki dolabında yasaklı kitap bulundurduğu için Gökyüzü romanının kahramanı da Trablus'a sürgün edilir. Kahraman, sürgün yerinde hakkında bir tahkikat yapıldığı takdirde bu sefer de Fizan' a sürüleceğini bile bile yasaklı kitapları okumaya devam eder. İnsanın yokuştan inerken aşağıdaki tehlikeyi görse de duramayacağı, yolunu değiştiremeyeceği inancı ve de korkusuyla Nâmık Kemâl'in şiirlerinden "Kemend-i cangüdazı ejderi kahrolsa cellâdın.../ Top olsa atılsa bağrıma arz [Olmazdı gönül yine hirasan]” (s. 18) mısralarını okur. Kahraman, hürriyet mücadelesinden, vatan için ölmek mutluluğundan, fedakârlıktan söz edenin bir karşı güç tarafından tehdit edilme riski taşıdığı bilincindedir. Son Sığınak’ta Zekazik kampında; roman kahramanı Süleyman ve arkadaşlarının ellerinde eser olmadan yalnızca akıllarında kalanlarla "Vatan yahut Silistre" (s. 36) oyununu oynamalarının onlara ümit aşıladığı, kahramanın hatıraları arasında gösterilir. Akşam Güneşi’nin kahramanı Nazmi de gerçekte idealist bir asker değildir ancak onun da aklında "Vatan yahut Silistre" (s. 65)den bir tirad vardır.

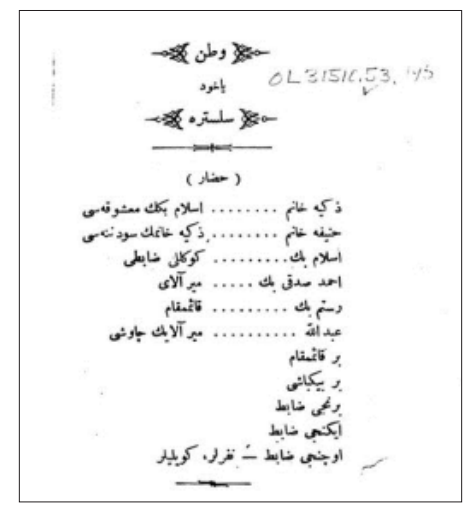

Vatan yahut Silistre ${ }^{39}$

Reşat Nuri, romanlarında yasaklı kitaplardan söz ederken bir taraftan da ilk romanı olan Gizli El'in Dersaadet'te (İstanbul'da) tefrikasına başlama aşamasında ne şekilde sansüre uğradığını, kitap olarak basıldıktan sonra "İlk Romanımın Romanı" bölümünde anlatır. Köprüyü geçmeye para bulamayan insanların yolsuzluk ve nüfûz ticaretiyle birdenbire harp zengini oluşlarını hicveden bir roman yazmayı tasarladığını ancak sansüre uğradığı için romanını değiştirmek zorunda kaldığını ifade eder ve "ötesi, berisi değiştirilmeden çıkan yazı yok gibiydi” (s. 6) diyerek dönem hakkında fikir verir. Güntekin; gizli eli, yazılar tefrika edilmeden inceleyen ve onay makamında olan Sansür Şemsi Efendi olarak görür ve "ilk romanımı [bu elle]/onunla beraber

39 https://tr.wikipedia.org/w/index.php?title=Dosya:Vatan_yahut_Silistre.pdf\&page=6 (Son Erişim: 10.07.2021) 
yazdığımı söylemek pek yanlış olmayacaktır” (s. 7) sözleriyle okuyucuya Şemsi Efendi’nin romana ne oranda müdahale ettiğini gösterir. Modern dünya ölçütlerine göre gülünç ve basit olarak değerlendirilen pek çok husus, aydınların ve sanatçıların önüne aşılmaz bir engel olarak konulur. Günümüzde traji-komik olarak görülen sansür nedenleri, Güntekin için de "artık kendimi tutamayarak gülmeye başlamıştım” (s. 7) denilecek seviyededir. Romanın ilk bölümünde sözü edilenler, dönemin toplumsal sorunlarının kaynağını göstermesi bakımından değerli bir örnektir. Güntekin’i öfkesinden gülme noktasına getiren sansür örneklerinden biri şöyledir:

Roman, "Bugün bir odun meselesini konuşmak üzere nazırı görmeye gitmiştim..." diye başlıyordu. Şemsi Efendi, “Odun olamaz. Yerine başka bir şey koyacağı”” dedi (...) Meğer o zaman Damat Ferit hükümetinin bir odun skandalı varmış. Sebep buymuş! "Sonra 'nazır' kelimesine izin yok. O da değiştirilecek, müdir-i umûmî fỉlan dersiniz. Sonra, Nişantaşı ve Bebek kelimeleri değişecek. Malum ya, Bebek, Damat Ferit Paşa'nın Baltalimanı'ndaki yalısına yakındır. Nişantaşı ise, vükelâ mahallesi... (s. 6-7)

Romanı yaşamın bir parçası gören Güntekin, insanı ve toplumu etkileyen hemen her konuya romanlarında yer verir. Hatta romanı yalnızca bireysel bir davadan da ibaret görmez. Nitekim Güntekin; Sansür Şemsi Efendi’nin “Canım, roman demek aşk ve alaka demektir!” ... "Onları bırakıp da ne diye uğraşırsınız böyle kazalı şeylerle... Şu devlet adamı ile vurguncunun karanlıkta işleyen gizli elini, mesela, güzel bir kadın eline çevirirseniz, biz de tatlı tatlı okuruz." (s. 7) sözleriyle toplumsal sorunlara duyarsız kalınmasını ve sadece aşk konularının işlenmesini isteyen insanların kimliklerini açığa çıkarma amacı taşır.

Damga romanında bir gazete sahibi Sami Beliğ Bey, gazetesinin "hükümetten para alan rezil paçavralardan [olmadığını]" (s. 94) belirtir. Hükümet desteğiyle yayın yapan gazeteler, sansürün farklı bir boyutunu oluşturur. Hükümetin istediği haberleri yapan, istemediği haberleri yapmayan bu yayın organları, özgürlük taraftarlarının gözünde rezil paçavralardan ibarettir.

Gazetelerin, dergilerin, kitapların, piyeslerin denetlendiği, toplu bulunulan mekânların gizlice izlendiği ve her şeyin tek elden kontrol edildiği istibdâd yönetiminde tüm kararlar Yıldız Sarayı'nda alınır.

\section{2. İstibdâdın Yönetim Merkezi: Saray}

Miskinler Tekkesi'nde roman kahramanı, dedelerinden biri olan Kocabaş Kazaskerden söz eder. Konağında neredeyse yirmi otuz halayık, aşçı, köle, ayvaz barındıran Kocabaş Kazasker, Sultan Mahmut'un sofrasında kaymak gördüğünde "Allah ömr-i şâhânelerini müzdâd eylesin. Abd-i fakîr ancak sa'y-i devletinde kaymak tadiyor. Yoksa kaymağa el sürmek biz gibilerin haddine mi düşmüş?” (s. 10) diye padişahı yüceltmeye yönelik dualar eder. Padişah, saray çalışanları için velinimet olarak görülür. Onun yediği ekmeğin kırıntıları yüze göze sürülür. Özel yapım sedef kutulara konulan, Sakal-1 Şerif gibi kat kat işlemeli bohçalar içinde saklanan padişah artıkları, yeni doğan çocuklara ömrünce yiyeceği ekmeğin zahmetsiz ve sıkıntısız olması 
için “teberrüken” tattırılan “ilk dünya nimeti” (s.10)dir. Yeşil Gece'de Dâr'ülmuallimîn'de hazır yemek, hazır yatak bulmak, çamaşırların yıkanması, söküklerin dikilmesi hadisesi; "saraya damat olma[k] [gibi]" (s. 46) algılanır. Nitekim Değirmen romanında sarayda yetişenler büyük bir rahatlık ve konfor içindedir. Roman; doğrudan sarayın sefahati ya da Anadolu'nun ihmal edilmişliği ile sefaleti üzerinden anlatılmaz, "sefalet ve sefahat" ince bir işçilikle deprem üzerinden kurgulanır. Depremle meydana gelebilecek "yıkıntı, göçük ve çöküş”; aslında bürokrasinin, devletin çöküşü olarak sezdirilir ve bu durum, panoromik bakışla gösterilir. Küçük bir depremle pek çok itibarın yıkılabileceği, bürokraside üst makamda bulunanların kendilerini kurtarmak için altındaki memuru kolaylıkla harcayabileceği işlenir. Osmanlı'nın son zamanlarında halk ile saray arasındaki uçurum hissettirilirken ihmal edilen Anadolu'nun bir sürgün yerinden farkının olmadığg üzerinde durulur. Anadolu'nun bir kasabasında yaşanan küçük çaplı bir depremin büyük bir deprem olduğu, kasabada ciddi hasarın meydana geldiği, başta kaymakam olmak üzere pek çok insanın yaralandığı hikâyeleri İstanbul'a, saraya hatta Avrupa'ya yayılır. Şehzade ile birlikte Avrupalı gazetecilerin kasabayı görmeye geleceği ve yardımda bulunacağı duyurulur. Bunun üzerine kasabaya hasar tespiti için daha önceden gönderilmiş mutasarrıf, vali gibi üst düzey devlet görevlileri; olayın söylendiği gibi olmadığının anlaşılmasıyla azledilebilecekleri korkusu içinde büyük deprem yalanını sürdürürler. Gerçekten harabe durumda olan evleri, küçük çaplı bir müdahaleyle biraz daha sefil duruma getirme kararı alırlar. O zamana kadar Beykoz'dan öteye, Ortaköy veya Çengelköy’den başka bir köye gitmemiş Şehzâde Şemsettin Efendi, daha Sarıpınar'1 uzaktan görür görmez köyün doğal hâlini depreme maruz kalmış zanneder ve "Hakikaten harabe haline gelmiş biçâre şehir... Vah, vah, vah..." (s. 141) diye üzüntüsünü ifade eder. Ardından yepyeni kıyafetlerini giyerek selam vaziyetindeki halk1 gördüğünde "Ne sefâlet yarabbî, ne sefâlet!..zelzele ne kiyâfete sokmuş zavallıları" (s. 141) diye iç çeker. Oysa şehzâdenin gördükleri, aslında ihmal edilmiş Anadolu'nun gerçek yüzüdür ve deprem yıkıntısı olarak şehzâdeye sunulan halkın gerçek yaşamıdır. Şehzâde, Anadolu'yu da İstanbul gibi mamûr yerler olarak düşünmektedir ki "Zelzelenin ne korkunç bir âfet olduğunu şimdi anladım. Birkaç dakika içinde bir mamûreyi ne hâle getirmiş" (s.142) diyerek saray ve çevresinin gerçeklerden uzak bir yaşam sürdüklerini gözler önüne serer. Değirmen'de Anadolu'dan habersiz, gördüklerinin yalnızca depremin yıkıntısı olduğu yanılgısı içinde olan saray efrâdının aksine Kavak Yelleri'nde Kurtuluş Savaşı'nın son yıllarında Anadolu'nun içinde bulunduğu durumun farkında olan, "Gençler Anadolu'ya" (s. 85) parolası ve şuuruyla onun imarı için harekete geçen gençler anlatılır.

Ateş Gecesi'nde Kemal Murat'ın ülkede işlerin bozulduğunu ifade etmesi, hak, hürriyet, adalet kalmadığı yönündeki tenkidi, kardeşleriyle kendisinin suçsuz oldukları hâlde sağa sola sürülmelerine isyanı, asker emeklisi babası tarafından yadırganır. Zira babasına göre böyle fikirleri düşünmek ve söylemek onların aklının alamayacağı şeylerdir. Böyle şeyleri düşünmek, dillendirmek "Her şeyi herkesten iyi bilen Şevketmeap Efendimizin irâdesine muhâlif[liktir]... Ona isyân Allah'a isyândır.” (s. 92) 
Gökyüzü’nde roman kahramanı, Sadi'nin Gülistan'ından bir bölüm okur. Kahramanın okuduğu bölüm saray ile halk arasındaki uçurumun derinliğini ve halkın saraya karşı içten içe küskünlüğünü yansitır:

Karlı bir kış gecesi padişah baştanbaşa samur kürklerle donanmış sıcak sarayında sabaha kadar eğleniyor; yarı çıplak bir fakir, pencerenin altında soğuktan titriyor. Nihayet sabah oluyor. Fakir başını kaldırıyor, sükûnetle: "Senin gecen de geçti; benim gecem de geçti” diyor. (s. 130-131)

Yeşil Gece'nin kahramanı Şahin Hoca; Anadolu ve Rumeli köylerinde gördüğü geri kalmışlığın, miskinliğin, faciaların nedeninin önceden müderrislerde, ulemalarda olduğunu düşünür. Ancak zamanla "bütün kabahat[in] halifede" (s. 32) yani Abdülhamid'de olduğuna kanaat getirir. Abdülhamid'e karşı bir isyan hareketi başlasa önde yürüyecek olan Şahin Hoca; birkaç yıl içinde gelişen “Meşrutiyet'in İlânı”na da “Otuz Bir Mart İsyânı”na (s. 32) da ilgisiz kalır. Kişilerle değil fikirle mücadeleye başlar.

Değirmen' in kahramanı Kaymakam Halil Hilmi Efendi, yaşanan ufak çaplı depremde küçük bir yara alır. Ancak onun bu durumu üst makamlara ağır yaralı olarak yansıtılır. Bunun üzerine mutasarrıf tarafından kaymakamın yerine vekâlet etmesi için bir kişi gönderilir. Büyütülen bu olay, kaymakamı geçici de olsa koltuğundan etmiştir. Kaymakam, başına gelenlerin sorumlularını sıralarken aslında sorumluların hiyerarşisini ortaya koyar. Nihayetinde yaşanan itibar cellâtlığının ucunun padişaha kadar uzandığı okuyucuya gösterilir. Değirmen romanında yaşanan küçük deprem, halktaki ve bürokrasideki yozlaşmayı gün yüzüne çıkarır. İnsanların arkadan kolaylıkla iş çevirdikleri, yıllarca birlikte yaşayan insanların birbiri hakkında kime ne tür bilgiler verdiğinin belirsizliği ve kişilerar asında büyük bir güven sorununun yaşandığı satır arasında verilen bilgilerdendir:

Yaktılar beni hainler, yaktılar. (...) Yakan hainler kim? Nereden bilsin o? İstanbul gazetelerine telgraf gönderen gazeteci; mutasarrıfa telgraf gönderen jandarma kumandanı; kendisi için ağır yaralı diyen doktor; günlerden beri kafasını şaşırtarak ciddî bir teşebbüste bulunmasına engel olanlar; bir suikast hazırlayan mutasarrıf, mutasarrıfa âlet olan vali; hülâsa uzun zulüm ve suikast zinciri ki ucu duvardaki çarpık ve tozlu çerçevesi içinden kalkık kaşlarının, büyük gözlerinin ebedî hayret ile bakan padişaha kadar gidiyor.

- Yaktılar beni hainler!.. (s. 76)

Klzılcık Dallarl ${ }^{40}$ romanının küçük yaşta bir konağa evlatlık verilen kahramanı Gülsüm, yaşadığı yeni yere uyum sağlamakta güçlük çeker. Konağın beklentilerine yanıt veremeyen, istenen formata girmeyen çocuk, büyükleri tarafından hor görülür; tartaklanır hatta romana adını veren "kızılcık dalları" (s. 163) ile darp edilir. Üstelik kardeşi İsmail'den ayrı bırakılan Gülsüm, ona karşı büyük bir özlem duyar. Konağın hanımı, onu İsmail'i görmeye göndereceğine söz verir ancak sözünü

40 Romanda Nevnihal Kalfa isimli kadının esassız kuruntuları anlatılır. Nevnihal Kalfa; çalıştığı konakta herkesin kendisiyle uğraştı̆̆ını, aleyhinde konuştuklarını zanneder. Bir yerlerden haber alabilmek için olağanüstü çaba sarf eder. Bu nedenle küçük bir çocuk olan Gülsüm'e "hafiyelik ettirmek” (s. 94) için uğraşır. 
tutmaz. Gülsüm de evden kaçma planları yapar. Yazar, küçük bir kızın yaşamının anlatıldığı Kızılcık Dalları'nın kurgusuna siyâsî bir sahne yerleştirir. Güntekin, Gülsüm'ün kardeşini görmek için yaptığı kaçma planının olanaksızlığını anlatmak için "Abdülhamid zamanında politikadan bahsetmek nasıl yasak idiyse konakta da "kaçmak"tan bahsetmek öyle yasaktır" (s. 75) diyerek Abdülhamid Dönemi’nde siyâsî söylemlerde bulunmanın zorluklarını okuyucuya hatırlatmış olur.

\section{Sahiplenilmeyen Meslek: Hafiyelik}

Güntekin'in romanlarında geçen bazı diyaloglardan hafiyeliğin çok yaygın olduğu ve hemen her yerde çok sayıda hafiyenin bulunduğu anlaşılır. Romanların bir kısmında hafiyelerin kimliği belli değilken bir kısmında ise kimliklerinin ortaya saçıldığg görülür. Hafiyeliğin yükselme, çıkar vasıtası olarak kullanılma, padişahın gözüne girme, birinin bulunduğu makama göz koyma gibi çeşitli amaçlarla yapıldığının örnekleri verilir. Güntekin'in muhtelif romanlarında aynen yer alan Ben hafiye değilim! cümlesi, toplumun hafiyeliğe bakışını özetler. Bu cümle, yazarın bazı romanlarında dönemin bir manifestosu ve leitmotiv olarak tekrarlanırken hafiyeliğin iyi bir şey olmadığı zihinlere yerleştirilmek istenir. Zira hafiyelerin yaptığı jurnallerle insanların hayatlarının karartıldığı, itibarlarının yok edildiği, sürgün ve tevkif edildiği bilinen bir gerçektir. Hafiyelerin yol açtığı travmatik hadiseler, insanların birbirine hafiye olabilir şüphesiyle bakarak güven sorunu yaşamasına neden olur. Böyle bir ortamda hafiye olsun ya da olmasın kendisinden en küçük şüphe duyulan bir insanın "Ben hafiye değilim” demesi, güven bunalımını daha da derinleştirir. Sık sık tekrarlanan bu cümle, pek çok insan tarafından yapılmasına rağmen hafiyeliğin itibarlı bir meslek olarak görülmediği iletisini taşır. Nitekim hiçbir romanda hiç kimse "Ben hafiyeyim" cümlesi kuramaz.

Damga romanında Vecdi Bey, meşrutiyet yanlısı olduğu gerekçesiyle jurnallenir. Jurnalleyenin “şevketmeap efendimizin en sadık bendegânından” Halis Paşa'nın oğlu İffet olduğu düşünülür. Oysa "Vecdi Bey'i jurnalleyen; onun yerine göz diken bir muallim[dir]" (s. 32). Olayın hakikati anlaşılmadan, hafiye olmadığı halde, İffet'e sadece saray adamının oğlu olduğu için okuldaki arkadaşları tarafından "hafiye" damgası vurulur. Sarayın yaptığı soruşturmada da İffet' in paşa oğlu olduğu için rahatlıkla hafiyelik yapabileceği düşünülür. Ancak İffet’ in bu konu hakkında bilgi vermemesi garip karşılanır ve eleştirilir. Durumu anlayan İffet, sorgulamayı yapan "Alman bıyıklı" (s. 23) yavere sinirlenerek "Ben hafiye değilim, yaver bey" (s. 24) diye tepki gösterir. İffet'in hocasını jurnallememesi ve soruşturmacıya tepki göstermesi babasına şikâyet edilir. Hafiye damgası yiyen İffet, okulu birakmak ister. Bunun üzerine sert tavırlı, hatta korkutucu gördüğü babası, İffet'e: "Muhakkak bana da öyle diyorlar ${ }^{41}$... Allah'a kasem ederim ki ben... hafiye değilim İffet...” (s. 29) der. Burada öne çıkan husus, saray ve çevresindeki herkesin hafiye olarak görüldüğüdür. Ancak durum böyle değildir. İffet ve paşa babası gerçekte hafiye olmadıkları hâlde hafiye olarak değerlendirilen kişilerdendir.

41 Telgraf gazetesi ile Selâmet-i Milliye gazetesi arasında bir kavga başlar. Selâmet-i Milliye gazetesinin sahibi Telgraf gazetesi çalışanlarını lekeleyen yazılar yazar. Telgraf çalışanı İffet de bu yazılardan nasibini alır. İffet, gazete çalışanlarının hedef alındığı makalede "devr-i menhus-1 zâilin en melûn hafiyelerinden birinin oğlu” (s. 103) olarak tarif edilir. 
Harabelerin Çiçeği’nde Doktor Hilmi Bey, jurnallenir ve Fizan’a sürgüne gönderilir. Jurnalleyenin kim olduğu başta bilinmez. Konakta, Süleyman'ın akrabası Hilmi Bey’i sürgünden Süleyman’ın paşa babasının kurtarabileceği konuşulur. Bunun üzerine konağın aşçısı, "Hani ne derler, zehirden şifa... (...) E, İstanbul bu. Ne olur, ne olmaz. Bir gün bir hafiyenin biri çıkar da... " (s. 30) diyerek Süleyman'ın babasının Hilmi Bey'i jurnallediğini ima eder. Süleyman'ın o zamana kadar anlamlandıramadığı "karanlık sözler” olarak aklının köşesinde kalanları, zehirden şifa, hafiye gibi sözcüklerle birleştirir. Nihayetinde kendi kendine söylediği "paşa babama, birçok kimselerin hafiye dediğini duymuştum" (s. 31) sözleriyle zihni aydınlanmaya başlar. Süleyman, babasına Hilmi Bey’in sürgününden sorumlu olup olmadığını sorduğunda babasının verdiği sert tepkiden onun hafiye olduğunu anlar. Ancak verecek bir yanıt bulamayınca babasına "Sen hafiyesin" demek yerine "Ben hafiye değilim." (s. 32) diyerek babasının hafiyeliğini ortaya koyar. Harabelerin Çiçeği’nde bu şekilde yakın akrabasını jurnalleyen kişiler görülürken Yeşil Gece'de öğrencilerini ve iş arkadaşlarını jurnalleyen müderrisler görülür. Bu müderrislerin ağzından çıkanları Allah kelamı gibi bir ibadet huşuu içinde dinleyen Şahin Hoca, sonradan bu insanların "saray kölesi ve Abdülhamid casusu olduklarını öğren[ir]" (s. 31). Ayrıca müderrislerin kendi evlatları saydığı medrese öğrencilerinin de içinde bulunduğu pek çok ocağı söndürdükleri dilden dile dolaşır. Bunlar öyle insanlardır ki "bir padişah selâmı, üç beş liralık bir ihsan için Allah'ı da Peygamber'i de tereddütsüz satarlar” (s. 31). Güntekin, müderrislerin arasında kötü olmayan kişilerin varlığına da değinir. Ancak "Abdülhamid istibdâdının en korkunç seneleri” (s. 31)nin yaşandığı dönemde azınlıkta kalan böylesi müderrislerin dışarıdakilerden çok kendi içlerindeki ulema arkadaşlarının "tekmesine uğrama[mak]”(s. 32) için gölgelerinden dahi korkar hâle geldiğini söyler. Ancak Güntekin'e göre iyilerin tarafında yer alanların korkuları, yapılan zulme sessiz kalmalarını mazur göstermez. Onlardan beklenen şey, böyle zamanlarda zulme rıza göstermek ve boyun eğmek değildir.

Yeşil Gece'de müderrisler ve softaların bir kısmının, sınıflarına mahsus kıyafetleri içinde hafiye olduğu işlenir. Son Siğınak'ta ise Makbule'nin zengin akrabasını tasvir ederken kullandığı "Frenkler gibi giyinen bir adam ama hafiye" (s. 40) ifadesi dikkat çeker. Böylece Batı tarzı giyimi benimsemiş kişilerin de hafiye olabileceği gösterilir. Daha genel manâda hafiyelerin her türlü kılığa kıyafete girebildiği ancak bu konuda şeklin şemâlin değil, zihniyet ve karakterin belirleyici olduğu ortaya konulur.

Kavak Yelleri'nde Cumhuriyet'in ilk yıllarının din görevlilerinden, zeki aynı zamanda vesveseli müftüsü, Şeyh Sait vakasının olduğu dönemde bir kazaya uğramaktan (asılmaktan) son anda kurtulur. Bu olay, müftüyü gölgesinden korkar hâle getirir. Cumhuriyet' in ilk yıllarında da gericilik ithamı ile yaftalanacağı kaygısı taşıyan müftü, her firsatta Cumhuriyetçi olduğunu söyler. Cumhuriyet balolarını kaçırmaz. "Sakalını bile birkaç günlük uzunca bir tıraş seviyesine indir[ir]" (s. 52). Hatta müftü, "hocaya benzememek gayretiyle kendini İstanbul'daki Protestan İncil satıcılarına benzet[tir]” (s. 106). Yaşadıklarının etkisiyle şüpheci ruh hâline bürünen müftü, din işlerine dair soru sormak isteyenleri dahi "Arife akşamı teşrif edersin... Ondan 
evvel Müftü, hanesinde yoktur” (s. 107) diyerek geçiştirir. Toplumun hafizasında yer edinen ve olumsuz etkileri nedeniyle izleri kolay kolay silinmeyen hafiyeliğin verdiği zarar, müftünün yaşadığı bir olayla okuyucuya gösterilir. Müftü, rüyasının yorumlanmasını isteyen bir kadını sivil polis zanneder. Onun bu tür vesveselerinden haberi olmayan kadın, müftünün ulema olduğunu düşündüğü için rüyayı yorumlamasını istediğini söyler. Endişeye kapılan müftü: "Ben ulema mulema değilim kadın. Ben laiğim lâik. Ağzımı mı arıyorsun, nedir? (...) taharri memuru musun nesin? Defol yanımdan” (s. 108) sözleriyle sert bir karşılık verir. Bu olay, Cumhuriyet'in ilk yıllarında dahi istibdâd döneminden kalma hafiyelik ve jurnal hatıralarının insanları büyük bir korku ve kuruntu içinde yaşatmaya devam ettiğini anlatır.

Bir kısım insanların hafiyelik ve jurnalcilikle maddî çıkar veya makam elde etmesi; ahlâklı, dürüst insanların yaşamlarını sıkıntıya sokar. Yakınlarından jurnalcilik yapması yönünde baskı gören ve bu konuda çatışma yaşayan insanların açmazları Acımak romanında işlenir. Romanın kahramanı Mürşid Efendi, karısı ve karısının annesinin etkisiyle istemediği işlere sürüklenir. Ancak ikisini de memnun edemez. Karısı, Mürşid Efendi’yi lüks bir yaşam için hırsızlığa teşvik eder. Defterdarın valiyi saraya jurnalleyerek İstanbul'a müsteşar olarak atandığı örneğini vererek Mürşid Efendi’nin de saraya birini jurnallemesini ister. Bu şekilde Mürşid Efendi'nin bir makama getirileceğini düşünür. Karısının sözlerini geçiştiren Mürşid Efendi, jurnale olan bakışını şu sözlerle ifade eder: Curnalcılı̆̆ın hırsızlık kadar fena bir şey olduğunu bu tecrübesiz genç kadına nasıl anlatırsın? (s. 119)

Anadolu' da fikirlerin geri kalmasını, işlerin kötüye gitmesini, halkın "yeşil bir gece içinde" (s. 43) yaşamasına bağlayan Yeşil Gece'nin kahramanı Şahin Hoca, gezdiği ilkokulları, memleketi karanlığa boğan medreselerden farklı görmez. Buralardan yetişen çocuklar için üzülen Şahin Hoca, bu eğitimden sonra onlara ne olacağını aklından geçirir. Çocukların bir kısmının "bu sevimsiz izbelerden"(s. 43) kaçarak çiftçiliğe sığınacağını, bir kısmının adına Ebcet dedikleri şeyleri öğreneceğini ve bu ne ölüye ne de yaşayana yararı olmayan şeylerle kendileri başta olmak üzere çevrelerine de zarar vereceklerine inanır. Bu çocuklar da büyüdüklerinde önceden kendileri gibi yetişmiş babalarının ya da ağabeylerinin yerini alacaktır. Onlar da bugünkülerin ne yapacaklarını ya da ne düşündüklerini bilmeyecek yalnızca "zararlı otlar gibi oldukları yerde büyüyüp kuruyacaklar yahut büyüklerin İstanbul'da bin şeklini gördüğü entrikalarına, menfaatlerine alet olacaklar, koyun sürüleri gibi gayesiz ölümlere sevk edileceklerdi[r]" (s. 43). Burada İstanbul sözüyle hükümet, İstanbul'dakilerin çıkarına hizmet eden ve entrikalara alet olanların da hafiyeler olduğu anlaşılır. Nitekim o dönemde İstanbul'da entrika için kullanılan kişilerin hafiyeler olduğu bilinmektedir. Romanlarında sayısız hafiyenin varlığından söz eden, pek çoğunun kimliğinin bilinmediğine her firsatta değinen Güntekin; esasen bu romanıyla hafiyelerin kimliğinden ziyade hangi zihniyetin gölgesinde hafiye olunduğuna dikkat çeker. Zira veril(mey) en eğitim, potansiyel hafiye üretmeye müsait bir ortam oluşturur. Ona göre çocukken alamadıkları eğitim nedeniyle idrakten yoksun kalmış çocuklar, büyüdüklerinde güdülmeye müsait ya sürüler olacak ya da zararlı otlar gibi oldukları yerde kuruyacak ve kimseye faydaları dokunmayacaktır. 
Hafiyeliğin bir dönem revaç bulması ve çok sayıda hafiye yetişmesiyle doğru orantılı olarak hafiyelerin hışmına uğrayanların sayısı da gittikçe artar. Attığı her adım izlenen şüpheli kişiler, bir gerekçeyle saraya jurnallenir ardından tevkif ya da sürgünle sonuçlanacak bir süreç başlar.

\section{Tevkif, Sürgün ve Sonrası}

Reşat Nuri’nin romanlarında sürgün iki yönlü işlenir. Bir tarafta sarayın muhalif veya tehlikeli gördüğü, hafiyelerin ihbar ve iftiralarıyla gerçekleştirilen sürgünler; diğer tarafta ise Meşrutiyet'in İlânının hemen ardından, insanların özgürlüğünü kısıtladığg değerlendirilen üst düzey kişilerin yönetimden tasfiye edilmesiyle gerçekleştirilen sürgünler vardır. Muhalif zihniyetlerin neden olduğu sürgün örnekleriyle sürgünün her hâlinin kötü bir şey olduğu, iktidar el değiştirdiğinde gelenlerin bir öncekinin yaptığı hataları tekrarladı̆̆ı gösterilir.

Sürgün, iktidarın hem kendini koruma refleksi hem de bir tür cezalandırma yöntemidir. Bir yönüyle de İstanbul' dan uzaklaştırılma anlamına gelir ve kişinin aldığı cezaya göre sürgün yeri değişiklik gösterir. Diğer sürgün yerlerine kıyasla İstanbul'a daha yakın Milas gibi yerlere en hafif cezalılar gönderilirken "sürgünler panayırı gibi bir yer” (Gökyüzü 14) olan Trablus'a siyâsî hükümlüler, İstanbul polisinin baş edemediği azılı hırsız, serseri ve zorbalar gönderilir. Hafiyelerin toplum vicdanında kabul görmemesine karşın onların gadrine uğrayan ve sürgün edilen kişiler gittikleri yerde saygınlık ve itibar görürler. Bu nedenle Trablus’ta bütün bu adî suçlular, "kendilerini politika mahkûmları, hürriyet fedaileri arasına karıştır[ırlar]" (s. 14) ve birer siyâsî hükümlü kisvesine bürünürler. Türlü ahlâksızlıktan bu yönüyle sıyrılmış olurlar.

Gökyüzü romanında Trablus’ta âdî suçlular, kendilerini hürriyet kahramanı gösterirler ancak onların suçlarını örtmek için kullandıkları uydurma kahramanlıkları, politik sürgün gelenler tarafından yüzlerine vurulmaz. Trablus; herhangi bir âdî suçlunun gerçekte siyâsî sürgün olmadığının kısa sürede tespit edildiği bir mahâldir. Dahası siyâsî sürgünlerin de tüm söylediklerini saraya anında yetiştirecek kadar "çok hafiye" (s. 15)nin bulunduğu bir yerdir.

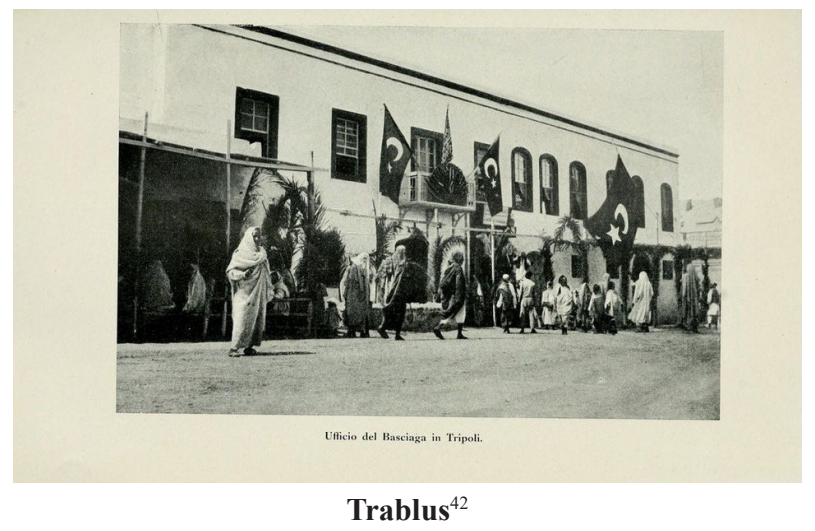

42 https://www.fikriyat.com/galeri/tarih/ilk-turk-pulu-ve-sonrasinda-tedavule-cikarilan-osmanli-devleti-pullari/210 (Son Erişim: 12.07.2021) 
Harabelerin Çiçeği 'nde roman kahramanı Süleyman, Abdülhamid' in yaverlerinden birinin oğludur. Süleyman, hatıralarını anlattığı romanın "Canlı Bir Mazi” bölümünde teyzesinin kocası Askerî Doktor Hilmi Bey’den söz eder. Hilmi Bey’in neşeli, sevimli, şakacı bir insan olduğunu; herkese anlayacağı dilde muamele ettiğini, hizmetçilerin, uşakların hastalıklarını, dertlerini dinlediğini, onlarla arkadaş gibi konuştuğunu belirtir. Babası da Hilmi Bey’in değerli bir insan olduğunu bilir. Ancak ona göre Hilmi Bey, "değil mi ki sadakati yok, değil mi ki şevketmeap efendimize kem gözle bakanlardan..." (s. 26) biridir. Dolayısıyla saray adamı için yalnızca padişaha sadakat, her türlü değerin üzerindedir. İnsanı insan yapan değerlerin bir önemi yoktur. Nitekim saray adamı için ülkenin içinde bulunduğu durumu sorgulamak, eleştirmek Abdülhamid'e karşı olmak demektir. Hilmi Bey'in paşayı, memleketin hâlini düşünmeye sevk eden cümleleri büyük bir kavgayla ardından da Hilmi Bey'in Fizan 'a ${ }^{43}$ sürgünü ile neticelenir.

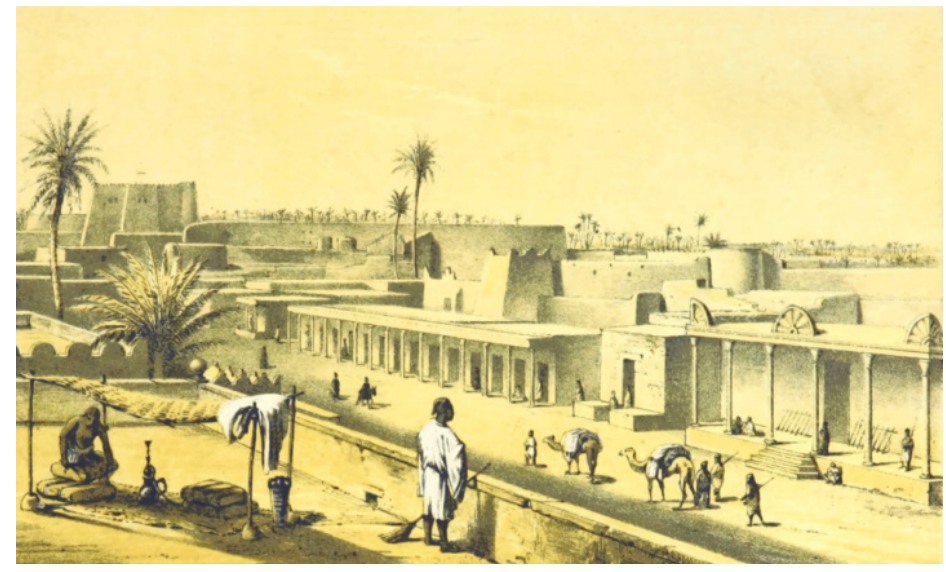

Fizan $^{44}$

Dudaktan Kalbe romanında Vedat, Kütahya'ya sürgün gönderilir. Sürgün geldiği Kütahya'da dayısı binbaşı olarak görev yapmaktadır. Dayısı Vedat'ın sürgün edilişine şaşırır. Onun politikayla uğraşmadığını bilen dayısı, sürgün nedenini sorduğunda Vedat, "Hiç vallahi, incir çekirdeği[ni] dolduracak şey değil... Bir Karagöz meselesi...”(s. 245) diyerek sürgün hikâyesini anlatır. Vedat, doktorluk mesleğinin yanında "ne yaparsın, bu memlekette insanın günü gününe uymuyor... Elden her iş gelmeli. ...iş bulamazsam” (s. 245) düşüncesiyle bir de Karagözcülük yapar. Bir gece davet edildiği yerde Nâzır (Bakan)da vardır. Nâzır, Vedat'ın Karagöz oynatmasını ister. Ancak Vedat, Nâzır için Karagöz oynatmak istemez ve bir an önce oradan ayrılmak ister. Ancak Nâzır küstahça ısrar edince Vedat, Nâzıra ders vermek maksadıyla onun yakın zamanlarda yaşadığı bir rezaleti resmederek Karagöz oynatmaya başlar. Nâzırı aslında olduğu

43 Trablus, ikinci sınıf bir sürgün yeridir "bir de daha hatırlılar için Fizan diye bir birinci sınıf vardı[r] ki oraya gitmek kör kuyuya düşmek demekti[r]” (Gökyüzü 15).

44 https://i.redd.it/y2py5t4qatx41.png (Son Erişim: 14.07.2021) 
gibi uzun burunlu, uzun kulaklı, sivri sakallı olarak karikatürize eder, yanına da metresi olarak söylenen şişman Polonyalı bir kadın çizer ve onun çapkınlığıyla alay eder. Nâzır işi pişkinliğe vurarak gülse de Vedat oynattığı Karagöz'ün üzerinden yirmi gün geçmeden sürgün edilir. Bir doktor, Karagöz oyunuyla bir devlet görevlisini eleştirdiği için sürgün edilir benzer şekilde Gökyüzü’nde de İstanbul çapkınlarından Halil, devlet adına çalışan “bir hafiye[yi] dövdüğü için" (s. 19) sürgüne gönderilir.

Ateş Gecesi romanı kahramanı Kemal Murat da okulundan alınarak sürgüne gönderilenlerdendir. Sürgün edilme nedeni hakkında bir bilgiye sahip değildir. Saray çalışanı babası, ona hiçbir soru sormadan sadece söylenen yere gitmesi yönünde telkinde bulunmuştur. İstibdâd dönemi Milas Kaymakamı on sekiz yaşlarındaki gencin isminin Kemal Murat olduğunu öğrenince "hem Kemal, hem Murat öyle mi? E sen bu akıbete iki defa müstahak olmuşsun çocuğum" (s. 10) diyerek onu siyâsî suçlu zanneder. Kaymakam, Kemal Murat'1 çevresindekilere manâlı göz işaretleriyle "Hem Kemal hem Murat Bey'i size takdim ederim” (s. 11) şeklinde iki ayrı isim olarak sunar. Burada yazar, yasaklı Nâmık Kemâl ile Mîzâncı Murâd'ın isimlerini çağrıştırma amacı güder. Nitekim bir saray adamının oğluna Kemal Murat adını koyması, o dönem için yadırganacak bir husus olarak görüldüğüne göre bu isim tercihinin Güntekin tarafından bilinçli bir şekilde yapıldığı düşünülebilir.

Kaymakam, Kemal Murat'ın siyâsî sürgün geldiğini zannettiği için onu gördüğü andan itibaren Nâmık Kemâl'in ismini açıktan söylemeden şiirlerini ezberden okur. Nâmık Kemâl'in "vatan"1 konu alan Vâveylâ şiirinin "Feminin rengi aks edip tenine/ Yeni açmış güle misâl olmuş" mısralarını okuyan kaymakam, Kemal Murat’a Nâmık Kemâl’i kastederek “adaşın ok gibi yüreğe işleyen şiirler yazardı” (s. 15) der. Yine ismini açıktan söylemeden Nâmık Kemâl'in genç yaşlardan itibaren Kıbrıs Magosa 'd $a^{45}$ Sakız'da, Midilli'de bulunduğundan bahseder. Ancak Kemal Murat, sürgün nedenini bilmediği gibi Nâmık Kemâl ve şiirleri hakkında da pek bir bilgiye sahip değildir. Aklındaki tek şey, karşılaştığı insanların sordukları sorunun yanıtıdır: Evet, bu yaşta mektep sıralarından alınarak sürgüne gönderilmek için ben, hakikaten ne yapmıştım? (s. 28)

Bir zaman sonra aradığg yanıt babasından gelir. Babası, yazdığı mektubunda "hakikaten merak edilecek bir şey değil!" diyerek öncelikle Kemal Murat'ın sürgün nedeninin siyâsî olmadığını söylemeye çalışır. Böylelikle bu tavrıyla bir taraftan oğlunu rahatlatma diğer taraftan da saray adamı olmanın gereklerine uygun olarak sürgünü normalleştirme çabası görülür:

45 Nâmık Kemâl otuz sekiz ay Magosa'da sürgün olarak kalır. Edebî hayatının en yoğun dönemini burada yaşar. Íntibah adlı ilk romanı ile edebî tenkitlerini burada yazar. Âkif Bey, Gülnihal, Zavallı Çocuk ve Kara Belâ isimli tiyatro eserlerini yine burada kaleme alır. Celâleddin Hârzemşah, Kanije, Rüyâ, Tahrîb-i Harâbât, Tâkîb-i Harâbât, Bahâr-ı Dâniş gibi pek çok eser burada vücûda gelir. Ayrıntılı bilgi için bkz. Ömer Faruk Akün, "Nâmık Kemâl", İslâm Ansiklopedisi, 32, (İstanbul: Türkiye Diyanet Vakfi Yayınları, 2006), 369; Nâmık Kemâl Magosa'ya gittiğinde otuz sekiz yaşındadır. Yazdığı makaleleriyle gençliğe ve topluma tesir etmiş, ülkede büyük bir şöhret kazanmış, üstelik bir hükümeti kendisi hakkında tedbir almaya mecbur bıraktıracak kadar olayları ve vicdanları zorlamada başarılı olmuş bir şahsiyettir. Recaizade Mahmut Ekrem, Abdülhak Hamid Tarhan gibi dönemin edebiyatını yapanlar onun takipçisidir, ondan fikir alıp ondan nasihat beklerler. Nâmık Kemâl; pek çok kişiye yol göstermiş, yenilik için mücadele etmiş, ümit aşılamıştır. Magosa'da bulunduğu otuz sekiz aylık zaman zarfında hayret uyandıracak derecede eser üretmiştir. Tanpınar, Edebiyat Üzerine Makaleler, 230-231. 
Biliyorsun ki, Sabiha Yengen, Veliaht Reşat Efendinin saraylılarındandır. Yengeni alırken bunun rızâ-yı şâhâneye mugayyir bir şey olduğunu anlayamamıştık. Beni besbelli ihtiyar ve alil diye adam yerine koymamışlar. Fakat sizin, üç kardeş, söylediğim yerlerde ikâmet etmenize dair irâde-i seniyye sâdır olmuş. ... Bunları sana kulağında bulunsun diye söylüyorum. Fakat sen, sakın kimsenin yanında tekrar etme. (s. 33)

Reşat Nuri, romanlarında istibdâd döneminde yalnızca siyâsî nedenlerle insanların sürgün edilmediklerini, sarayın hoşuna gitmeyen küçük bir mevzudan dolayı da genç yaşlı denmeden insanların sürgünle cezalandırıldıklarını gösterir. Ateş Gecesi romanında sürgüne neden olan suç, babanın işlediği iddia edilen suçtur. Abdülhamid'in rızasına aykırı bir evlilik yaptıran baba, ihtiyar ve alil diye adam yerine koy [ulmayarak] cezadan muaf tutulmuş ancak evlenen oğlu, kardeşleriyle beraber farklı yerlere sürgün edilerek cezalandırılmışlardır.

Gökyüzü romanının kahramanı, amcasının kendisini defalarca uyarmasına aldırmayarak pervasız bir şekilde politikadan veya döneminde tehlikeli olarak görülen türlü fikirler hakkında konuşur ta ki bir gece müdür odasına çağrılana kadar. Roman kahramanı da saraya jurnallenmiştir. Kahramanın "beni saraya kimin ne şekilde jurnal ettiğini ne o vakit ne de sonradan öğrenemedim" (s. 12) dediği gibi hafiyelerin kim olduğu yine belli değildir. Okuldaki dolabında bulunan yasaklı kitaplar ve bu kitapların kenarlarına yazdığı notlar, onu korkunç bir ihtilâlci tanıtmaya yetmiştir. Karakolda yaşadığı günleri yaşamının en kötü günleri olarak hatıllayan kahraman, bu hatıralarını daha sonraki zamanlarda bir övünç vesilesi görür. Bu kitapları okuduğu için ihtilâlci damgası yiyen kahraman, karakolda yaşadıklarından sonra kendisine bir şans verildiğinde belki de dünyanın en uysal insanı olacaktır. Ama "ne yazık ki hâkimin düşeni kaldırmaya, kırılanı tamire vakti yoktur; onun işi sadece suçluyu vurmaktır" (s. 13) denilerek hukuk sisteminde peşin hükümlülüğe daha doğrusu adaletsizliliğe dikkat çekilir. Ayrıca yasaklı kitap okumanın, pervasızca, uluorta politika konuşmanın sıkıntılı ve ağır sonuçlarının olduğu kahramanın şu sözleriyle ifade edilir: Böyle bir meselede bir kere kâ̆ğlda mürekkep damladı mı kimse bir şey yapamazdl. (s. 13)

Güntekin'in romanlarında yasaklı kitap bulundurmaktan, sağda solda politik konuşmalar yapmaktan ya da aile fertlerinden birinin işlediği iddia edilen suçtan dolayı sürgün edilenler olduğu gibi herhangi bir neden belirtilmeksizin yapılan sürgünler de vardır. Kavak Yelleri'nde Anadolu'nun bir kasabasında yıllardır doktorluk yapan İsa'nın öğrencilik yıllarından söz edilir. İsa, o dönemlerde askerî öğrencidir. “Abdülhamid 313'te Askerî Tıbbiye talebelerini bir vapura doldurarak Trablus'a, Hicaz'a, Bağdat'a sürdüğü zaman, saçlı sakallı bir adam olmasına rağmen nedense onu [İsa'yı] da aralarına kat[arlar]" (s. 102). Ancak İsa, bir şekilde yarı yoldan alınır ve bu kasabaya gönderilir. İsa'nın da diğer tıp öğrencilerinin de sürgün nedeni bilinmez. Ancak yazarın burada dikkat çektiği husus, insanların dış görünüşlerinin herhangi bir siyâsî dönemde sürgün nedeni olabilmesidir. Nasıl ki Miskinler Tekkesi'nin kahramanının kıyafeti, onun Ahrar Fırkasının üyesi sanılarak İttihatçılar tarafından sürgün edilmesine neden olur. Bu romanda da İsa, saçlı ve sakallı bir adamdır ve yazara göre saçlı ve sakallı birinin de Abdülhamid tarafından 
sürgün edilmemesi gerekir. Ancak o da diğer tıbbiyeliler gibi sürgüne gönderilmiştir. Bu durum şaşkınlıkla anlatılır. Dolayısıyla istibdâd döneminde yönetimde bulunanların insanların dış görünüşüne göre keyfi uygulamalarda bulunabildikleri gösterilmiş olur.

Gökyüzü’nde Trablus’a sürgüne gönderilmiş bir defterdarın yedi sekiz yaşlarındaki oğlu Mükerrem, roman kahramanının Trablus’taki sürgün yıllarında Fransızca ve Matematik öğrettiği bir çocuk iken yaşlılık döneminde yanından neredeyse hiç ayrılmayan dostu olur. Mükerrem de gençliğinde politikayla uğraştığı için bir sene Sinop’ta sürgün kalır. "Politikaya tövbe" (s. 45) ettikten sonra Belçika'da üniversite tahsili alır.

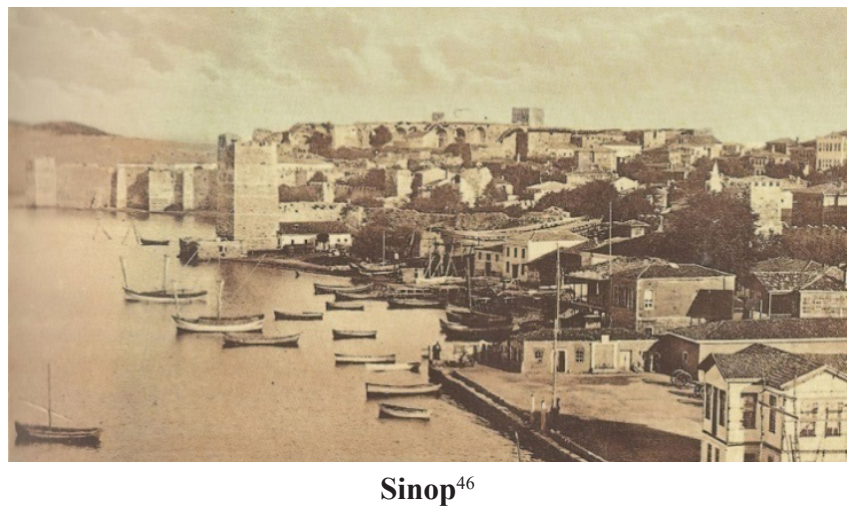

Son Sı ğınak’ta tiyatro sevdalısı bir askerin amatör arkadaşlarıyla ortaoyunu oynamak için toplandıkları bir gece, baskına uğrayışları anlatılır. Hafiyeler, "İstanbul'daki (Cöntürkler) Paris’teki Ahmet Rıza'nın emriyle Abdülhamid'e suikast hazırlıyorlarmış diye” (s. 30) jurnal verdiğinden bu baskın gerçekleşir. Neticede asker, hakkında hiçbir araştırma yapılmadan apoletleri sökülür; Adana'ya sürgün edilir. Abdülhamid'e suikast ithamı karşısında "Yahu, zurna ile dümbelekle, pişekâr şakşaklarıyla suikast hazırlanır mı?” (s. 30-31) denilerek yapılan eylemin traji-komik yönüne değinilir, alaycı bir yaklaşım sergilenir. Miskinler Tekkesi'nde roman kahramanının dayısı, Sultan Abdülhamid'in mabeyincilerinden biridir. Sarayda çalışmasına rağmen annesinden para alarak geçimini sağlar. Ödünç para almadan ay sonunu getiremeyen dayı, Meşrutiyet' in İlanıyla önemli paşalarla birlikte sürgüne gönderilir. Romanda Meşrutiyet' in

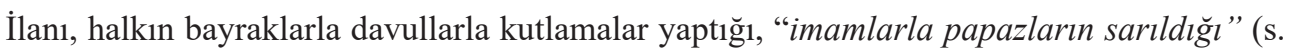
31) bir gün olarak hatırlanır. Güntekin, Meşrutiyet'i kutlayan halkın, önüne çıkanı götüren dalga gibi hareket ettiğine ve nihayetinde gördükleri ilk konağa çarptıklarına dikkat çeker. Halk galeyana gelerek bir saray çalışanının konağının kapısına dayanır ancak bu kapının bir hafiyeye ait olduğuna yönelik kesin bir bilgi de yoktur. Yapılan eyleme bakıldığında romanda doğrudan ifade edilmese de saray çalışanı olmak, hafiye olmak için yeterli bir gerekçedir. Halkın konağa saldırması; roman kahramanının, dayısına şüpheyle bakmasına neden olur:

46 http://www.eskiturkiye.net/4319/sinop-ve-sinop-kalesi (Son Erişim: 16.07.2021) 
Dayım, dedikleri gibi, kafası ezilecek bir hafiye miydi? İnsanın alacası içinde olduğuna göre belki evet... Fakat nümayiş yapanlar da bu meselede benden fazla bir şey bilmediklerine göre belki de hayır... (s. 31)

Damga romanının kahramanı İffet, babasının adına, Meşrutiyet İlan edildiği gün halkın sokaklarda "Kahrolsun Halis Paşa" (s. 33) sloganlarında rastlar. İffet, kendisini saltanat delisi olmayan ... doğuştan demokrat (s. 43) olarak tanımladığı ve buna göre hareket ettiği hâlde babasının Midilli’ye sürülmesinden olumsuz anlamda etkilenir. Gösteri yapan halk tarafından konağın camları kırılır, ailesi darmadağın olur, mallarına el konulur ve İffet, babasıyla birlikte Midilli' de gönüllü iki buçuk yıl sürgün olarak yaşamak zorunda kalır.

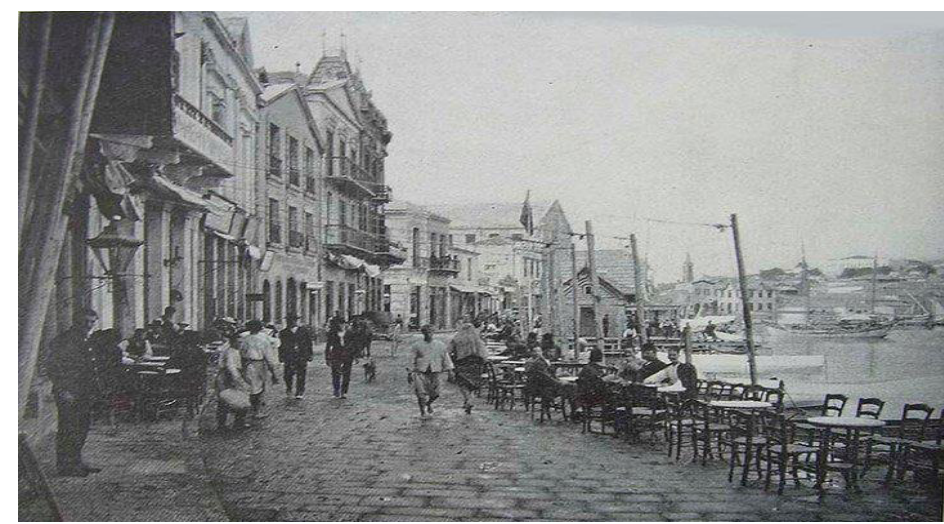

Midilli $1908^{47}$

Güntekin, o zamanki sürgünleri; gittikleri yerleri aydınlatan münevver propagandacılar olarak görür. Romanlarında kahramanlarını çoğunlukla siyâsî söylemlerden uzak tutan yazar, memleketin kötüye gidişi hakkında okuyucuya dolaylı bilgi verir. Örneğin; Ateş Gecesi’nde sürgüne gönderilen roman kahramanı siyâsî söylemlerde bulunmazken yönetimi üstü kapalı eleştirenin sürgün yerinin ve rejimin zorunlu taraftarı olan yahut görünen kaymakam olduğuna dikkat çekilir. Siyâsî sürgün zannedilen kahramana Nâmık Kemâl, Ziyâ Paşa ve diğer Tanzimat sanatçılarının şiirleri vasıtasıyla memleketin bir uçuruma doğru sürüklenişi yine kaymakamın diliyle anlatılır. Ancak kaymakamın ihtiyatı elden bırakmadığı ve konuşmalarında ileri gittiğini fark edip korkuya kapılarak "memlekette olup bitenden haberi olmayan masum ve iyi kalpli padişaha dualar et[tiği]” (s. 85) de görülür. Böylece, otoriter yönetimlerin insanları ikiyüzlülüğe zorladığı ortaya konulur.

Güntekin, bir başka muhalif ve siyâsî olmayan sürgün hikâyesini Değirmen' de işler. Değirmen romanında soyunda pek çok âlim, müderris, kazasker, bir şeyhülislâm ile bir evliyâ bulunan, Yıldız Sarayında Abdülhamid'in şehzadelerine ders veren Hacı Fikri Efendi'nin

47 https://ozhanozturk.com/2018/07/27/midilli-lesvos-lesbos/ (Son Erişim: 01.07.2021) 
şehzadelerden birini “domuz oğlu domuz” (s. 45) diye azarladığı için Bağdat’a sürgün edildiği örneği verilir. Yine aynı romanda Bulgar kökenli Nadya/Naciye isimli kızın sürgünü anlatılır. Sözde sahip çıkıldığı kasabada Nadya, "evlatlık olarak alındı̆̆ı bir evde on dört yaşını bitirmeden bir kazaya uğra[tılır]” (s. 25). Bu olay; ev sahibi tarafindan kapatılır ve Nadya, İstanbul'a gönderilir. "İstanbul['un] bir fazilet krizi geçir[diği]”'(s. 26) bir dönemde de Nadya gibi görünen Müslüman kokotlar, İttihatçılar tarafından öteye beriye sürülürler. Nadya, bu sürgünle yeniden kasabaya dönmek zorunda kalır. Çalıkuşu'nda Feride, Hayrullah Bey'in yanında hemşirelik yaparken savaşta ağır yaralanan Binbaşı İhsan Bey ile karşılaştığında Ç. Kasabasındaki günlerini hatırlar. Burada Feride'yi kimsesiz görerek gece âlemlerine sürüklemeye çalışan insanların karşısına İhsan Bey çıkmış ve Feride'yi ölme pahasına korumuştur. Değirmen romanında sürgün edilen Nadya gibi Çalıkuşu'nun Feride'si de "Yüreğimde, sürgüne gönderilen bir adi sokak kadını zilletiyle elimi suçsuz yüzüme kapayarak şehirden çıkıyordum” (s. 431) der. Güntekin, toplumun kimsesiz gördüğü kadınlara karşı bilinçli-bilinçsiz sergilediği tavrı gösterirken yönetimin de ayrıca mağduriyetlere neden olduğunu anlatmış olur. Nitekim Nadya, kimsesiz bir çocukken verildiği ailede istismara uğramış, ardından sanki bu durumu hak etmiş gibi bir de sürgün edilmiştir. Feride ise "çocukluğumdan, beni müdafaa eden bir babam, bir kardeşim, bir... Bildiğim [bir yakınımın] olmamasından istifade etmişler, beni gece âlemlerine sürüklemişlerdi” (s. 430) şeklindeki sözleriyle kimsesiz olduğu düşünülen kızların toplum yaşamında karşılaşabilecekleri durumlar ifade edilir.

Reşat Nuri, bir romancı, bir tiyatro yazarı, bir hikâyeci olarak yaşadığı dönemi sosyal ve siyâsî açıdan gözlemleyen, sonuçlarıyla birlikte ele alan, toplumla hayatla iç içe olan bir yazardır. Romanlarını belli bir dönemle sınırlamayan yazar her dönemi kendi içinde ve olduğu gibi işler. Tanpınar'ın Reşat Nuri hakkında söylediği “politikaya meydan okumak cesaretini gösterdiğini söyleyemem"48 sözleri belki de yalnızca Yeşil Gece romanı dişta tutularak söylenebilir. Atatürk'ün isteğiyle yazılan bu romanda zamanın şartlarına göre her kılığa bürünen softalar ciddi bir şekilde eleştirilir. Yeni Türkiye'nin temellerini oluşturacak eğitim sistemi, yaşam biçimi, giyim şekli gibi inkılâplar ve yenilikler yavaş yavaş bu romanla kendini gösterir. Romanda ideolojik bir hava gözlemlenirken Güntekin'in diğer romanlarında böylesi keskin bir tavırla karşılaşılmaz.

Her dönemin eğrisini doğrusunu yansıtmaya, okuyucuyu düşündürmeye çalışan Reşat Nuri, "en sert eleştirilerinde bile uslûbu son derece yumuşak"

Güntekin'in romanlarında yalnızca bir dönemin kritiği yoktur. Yazar, Abdülhamid Dönemi’nin yanlış uygulamalarını eleştirdiği gibi yeri geldiğinde İttihat ve Terakkinin yanlışlarını da demokrat bir tavırla tenkit etmekten geri durmaz.

Örneğin; Ateş Gecesi’nde, 1918 yılında ittihatçıların doğru bulunmayan eylemlerinin eleştirisi, Abdülhamid Dönemi sürgününden dönen ve sürgün edilmiş olmanın nimetlerinden

48 Tanpınar, Edebiyat Üzerine Makaleler, 441.

49 Enginün, Yeni Türk Edebiyatı Tanzimat'tan Cumhuriyet'e (1839-1923), 440. 
yararlanması gereken Kemal Murat'a yaptırılır. Romanda, yıkılan rejimin mirasçıları olarak görülen ittihatçıların kendi aralarındaki mücadeleler anlatılır. Onların da "zaman zaman yap[tıkları] temizliklerle" (s. 253) zayıfları ezdiği, susturduğu veya sürgün ettiği ifade edilir. Görüldüğü üzere Güntekin, kahramanını pragmatist davrandırmaz. Onun bu tavrı, okurun ders çıkarması yönünde eğitici işlev görür.

Öte yandan memurların İstanbul dışına gönderilmeleri doğrudan sürgün olarak adlandırılmaz ancak kimi zaman sarayın kimi zaman ittihatçıların sürgün denebilecek uygulamalarına rastlanılır. Değirmen'de bir Babıâli Bey'i olan Hamit Bey, Meşrutiyet'in ardından neredeyse altmış yaşından sonra İstanbul dışına çıkarılır. Kalamış’taki köşkünden sonra gittiği yer, ona “eski sürgünlerin gönderildikleri Fizan gibi görün[ür]"."” (s. 90) Sinir hastası olan karısının rahatsızlığg bu nedenle daha da ilerler, kendisini asmaya kalkar, tımarhanelik deli gibi olur. Mutasarrıf Hamit Bey ise karısından daha kötü durumlara düşer. Kalamış koyunu, Fenerbahçe'yi ağlayarak hatırladıkça kendisini buralara atanlara lanet eder.

Siyâsî görüş, sarayın hoşuna gitmeyen bir durum, giyim şekli, dış görünüş veya gerçeklikten uzak ve absürd pek çok nedenle saraya jurnallenen kişilere çeşitli cezalar uygulanır. Sürgün; jurnallerin sonucu olarak verilen cezaların en çok tercih edilenlerinden biridir. Güntekin'in romanlarında sürgün edilenlerin ve yakınlarının sürgün esnasındaki yaşamları ile sonrasındaki durumlarını betimleyen anlatımlar mevcuttur.

Miskinler Tekkesi'nde Meşrutiyet' in İlanından sonra kahramanın dayısı sürgüne gönderilince konak dağılır. Çalışanlar, mecburî olarak gönderilir. Kahraman, büyükannesi ve evin eski çalışanıyla birlikte ihtiyar bir kalfanın evine sığınmak zorunda kalırlar. Büyük borçlarla, mahkemelerle uğraşmak zorunda kalan büyükanne, son borcunu ödediği gün ölür. Konaktan yıllarca çıkmayan eş dost akrabanın hiçbiri, cenazeye katılmaz. Roman kahramanı da Meşrutiyet'ten sonra yapılan tasfiye ile işten atılır. Kahramanı dilenciliğe götüren sürecin başlangıcı olarak bu tasfiyeyi saymak yanlış olmaz. Zira işten atıldıktan üç yıl sonra kahraman da dayısı gibi sürgün edilmiş, okul hayatı, iş hayatı sekteye uğramıştır. Kahramanın sürgün edilme nedeni bir masalla açıklanır. Bu masalda ak koyuna binenin yedi kat gökyüzüne çıktığı, kara koyuna binenin yedi kat yerin dibine indiği anlatılır. İttihatçılar, ak koyuna; Ahrar firkası da kara koyuna benzetilir. Ne İttihat ne Ahrar firkasıyla ne de politikayla işi olan kahraman, başka bir elbisesi olmadığı ve "mabeyin biçimi redingot” (s. 36) giydiği için kısmetine kara koyun düşer ve Ahrar firkasına mensup zannedilerek sürülür.

Sürgün edilme, bir insanın hayatı boyunca üzerinden atamayacağı bir travma oluşturan psikolojik riskler içerir. Ancak kahramanın arkadaşları "darağacına ve hapse giderlerken” (s. 36) onların durumunu kendisiyle kıyasladığında sürgün, basit bir ceza olarak görülür. Güntekin'in kahramanının sürgün edilme nedenini bir masaldan yararlanarak açıklaması, o dönemde yapılan tevkiflerin, sürgünlerin gerçeklikten uzak nedenlere dayandığını göstermek için olmalıdır. Nitekim kişinin yaşamını olumsuz etkileyecek ve travmatik sonuçları olan sürgünün nedenlerinin ancak hayalî ve akla sığmayacak gerekçelere dayandırıldığg gösterilir. Gerçeklikten uzak hatta komik denebilecek 
nedenlerle yapılan sürgünün acıları yaşanan bir gerçeklik olarak ustaca bir arada verilir.

Gökyüzü’nde roman kahramanı, “Abdülhamid'in haksız yere zulmettiği, hayatını, istikbalini kırdığı insanlardan biri de benim” (s. 16) diyerek sürgün gönderildiği Trablus’ta kendisi gibi pek çok insanın bulunduğunu anlatır. Trablus’ta bir arkadaşı, onun saray ve padişah hakkında ileri geri konuşmaması, tedbirli davranması için vilayete yeniden jurnallendiği ve Fizan'a gönderileceği yalanını söyler. Fizan’a sürülmemek için Paris’e kaçan kahraman, ülkesinden on bir yıl boyunca ayrı kalır, ancak Meşrutiyet'ten sonra ülkeye dönebilir. Harabelerin Çiçeği'nde Hilmi Bey -ki roman kahramanı Süleyman'ın teyzesinin kocasıdır- Süleyman'ın babası tarafından jurnallenmiş ve Trablus'a sürgüne gönderilmiştir. Süleyman; teyzesinin kızı Seniha’yı sevdiği, Hilmi Bey’in sürgünü hak etmediğini düşündüğü için bu durumdan çok etkilenmiş, ancak çocuk yaşta olduğundan hadiseleri çaresizce izlemiştir. Sonuçta Hilmi Bey, Trablus'tan İstanbul'a dönemeden oralarda vefât etmiş; yaşarken ailesiyle birlikte büyük sefalet çekmiştir. Hilmi Bey’in torunu Nezihe, sürgünden zarar görenin yalnızca kendilerinin olmadığını, jurnalcinin de ettiğini bulduğunu hadiseden ve yangından masum olduğu halde en fazla etkilenen Süleyman'a, yani dedesini jurnalleyenin oğluna bilmeden söyler:

Amma, Allah onlara da çok fena bir şey yapmış efendim. (...) Nişantaşı'nda bir konakları varmış. O yanmış... Onun içinde de kıymetli, güzel bir oğulları varmış, o da yanmış!... (s. 94-95)

Çocuk yaşında Hilmi Bey’in sürgününü kabullenemeyen, babasının hafiyeliğini deşifre eden ve konakta çıkan yangında yüzü yanan Süleyman, teyzesinin daha önceki evini satın alır ve yıllar önce babasının yaptığı kötülüğü bu şekilde telafi etmeye çalışır. Bu çerçevede Harabelerin Çiçeği’nde verilen iletilerden biri de bir hafiyenin veya jurnalcinin kötülügünden küçük büyük pek çok masum insanın çevresiyle birlikte olumsuz etkilendiğidir.

\section{Sonuç}

1876-1909 yılları arasında otuz üç yıl Osmanlı Devleti’ni yöneten II. Abdülhamid; Osmanlı padişahları arasında kendisinden hayli söz ettiren, yaşadığı dönemde kiminin en büyük düşmanı, kiminin en azizi olarak algıladığı siyâsî bir aktördür. Uygulamaları nedeniyle Abdülhamid'i baskıcı, sansürcü ve otokrat bir şahsiyet olarak görenlerin karşısında onu; bir devlet adamı, manevî bir şahsiyet olarak tanımlayanların ötesinde Abdülhamid'e isyanı, Allah'a isyan etmekle eşdeğer sayanlar dahi bulunur. Abdülhamid; kendisinden önceki padişahların yaşadığı olumsuz durumları yaşamamak, vehimlerini ve korkularını bastırmak amacıyla hafiye teşkilatı kurar ancak bu teşkilat zamanla bir takım kirli hesapların, çıkar çatışmalarının aracı hâline gelir. Cemiyet içinde kangren olarak algılanmaya başlanan teşkilat, 31 Temmuz 1908'de devlet müdahalesiyle kesilip atılana dek sosyal, siyasal pek çok buhrana neden olur. Döneminin siyâsî ve sosyal durumunu romanlarına yansıtan Reşat Nuri Güntekin, hafiyelik ve jurnal konularını farklı romanlarında ana konunun yanında tâli unsurlar olarak işler. Güntekin'in romanlarına hafiyelik ve jurnal kavramları doğrultusunda bir bütün olarak bakıldığında yazarın, istibdâdî 
yönetimin toplumsal ve siyâsî yansımalarını konu edinen genel bir resim çizdiği anlaşılır. Halkın bakış açısıyla çizilen bu resim, renkli değil siyah beyazdır. Siyah kısmını saray ve çevresi, beyaz kısmını ise muhalifler ya da muhalif zannedilenler oluşturur. Resimdeki ana figür olan halk, mutlak otorite ile çevrelenmiş; hafiyelerle izlenmiş, bir kısmı jurnallerle suçlanmıştır. Panoramik resmin ilerleyen bölümlerinde tevkif edilen ve bazıları da uzak yakın birtakım yörelere sürülen aydın düşünceli insanlar bulunur.

İnsanlar arasında derin itimatsızlık, endişe, korku oluşturan, zamanla toplumun birlik ve beraberliğini zedeleyen, insanları birbirine düşman eden hafiyelik ve onunla birlikte ortaya çıkan yasaklar, tevkifler, sürgünler; aydın kimliğiyle toplumun sorunlarını gözlemleyen Reşat Nuri Güntekin'in romanlarında yardımcı unsurlardandır. Akılıı hareket eden, oldukça zeki ve iyimser bir kişi olan Güntekin, facia boyutunda gördüğü hafiyelik ve jurnal konusunu ölçülü bir üslûpla işlediğinden okuyucuda yalnızca ahlâki endişe hissettirir. Hafiye ve jurnalcileri doğrudan bir kin ve nefret objesi olarak göstermez. Bununla birlikte insanlarda ciddi rahatsızlık oluşturabilecek durumlar, yeri geldiğinde mümkün olduğunca yumuşatılarak verilir ki bu bir çeşit yazarın kendine uyguladığg sansür (otosansür) dür. Güntekin söz konusu uygulamayı devletçi bir anlayışla yapmaz, sorunun kökenini tespit ederek çare yollarını işaret eder. Hafiyeliğin küçükten büyüğe toplumun pek çok kesimine olumsuz etki eden yönlerine dikkati çeker. Bu nedenle hafiyelerin kimliği onun ilgi sınırları içine fazlaca girmez. O; kişileri değil, zihniyeti hedef alır. Ona göre; insanları absürd gerekçelerle suçlayan, karalayan bu zihniyeti besleyen ortam, akıl ve bilim ile hareket edilerek kurutulduğunda, bu tür gayrî insanî faaliyetler temelden yok olacaktır. Romanlarını realist bir çizgide ele alan Güntekin, yaşadığı her dönemi derin bir süzgeçten geçirir ve sorumluluk bilinciyle yazar. Örneğin hürriyet ve adalet taraftarı olarak gösterdiği ve bu nedenle tevkifler, sürgünler yaşattığı kahramanlarının taraftarı olduğu bir grubun siyâsî gücü ele geçirdiklerinde benzer haksızlıkları yaptıklarını eleştirmekten de geri durmaz. Yazarın örtülü amacı okuyucuda insanî yönetim bilinci oluşturarak yönetimin ya da partilerin kutsanmasının önüne geçmektir.

Diğer taraftan Güntekin romanlarında, siyâsî olayların uzun vadede insanlar üzerindeki etkilerini gösterir ve okuyucunun dönem hakkında fikir yürütmesini olanaklı hâle getirir. Örneğin; hükümetin onaylamadığı bir kitabı okuduğu için on yedi on sekiz yaşındaki bir gencin okul sıralarından alınarak sürgün edilmesi ve yıllarca eğitimden yoksun kalması; ülkenin gidişatını sorguladığ 1 için bir doktorun yurt dişına sürgünü ve orada sefalet içinde ölmesi; ortaoyunu oynayan bir askerin jurnallenerek sorgusuz sualsiz apoletlerinin sökülmesi, okuyucunun siyâsî ortam hakkında çıkarımda bulunmasını sağlayan malzemelerdir. Güntekin; bir yönüyle yangın yerine dönmüş ortamı ve siyâsî gerçekliği derinlemesine hissettiren diğer yönüyle her döneme ve kişiye tolerans tanıyan; üslubu, bakış açısıyla her geçen gün etki alanını genişleten ve ilgi çeken usta bir romancıdır. 
Hakem Değerlendirmesi: Dış bağımsız.

Çıkar Çatışması: Yazar çıkar çatışması bildirmemiştir.

Finansal Destek: Yazar bu çalışma için finansal destek almadı̆̆ını beyan etmiştir.

Peer-review: Externally peer-reviewed.

Conflict of Interest: The author has no conflict of interest to declare.

Grant Support: The author declared that this study has received no financial support.

\section{Kaynaklar/References}

Ahmet Cevdet Paşa. Tezâkir, Haz. Cavid Baysun, II. Seri, Ankara: Türk Tarih Kurumu Basımevi, 1967.

Akün, Ömer Faruk. "Nâmık Kemâl'in Kitap Halindeki Eserlerinin İlk Neşirleri.” Türkiyat Mecmuası, 18, (1976): 1-78.

Akün, Ömer Faruk. "Nâmık Kemâl." İslâm Ansiklopedisi, 32, İstanbul: Türkiye Diyanet Vakfı Yayınları, (2006): 361-378.

Akyüz, Kenan. Modern Türk Edebiyatının Ana Çizgileri, İstanbul: İnkılâp Kitabevi, 1995.

Akyıldız, Ali. II. Abdülhamid'in Çalışma Sistemi, Yönetim Anlayışı ve Babıali'yle (Hükümet) İlişkileri, Osmanlı, III. Ankara: Yeni Türkiye Yayınları, (1999): 286-297.

Akyıldız, Ali. "Mabeyn-i Hümâyun.” İslâm Ansiklopedisi, 27, İstanbul: Türkiye Diyanet Vakfı Yayınları, (2003): 283-286.

Arşiv Belgelerine Göre Osmanlı'da İstihbarat. T.C. Başbakanlık Devlet Arşivleri Genel Müdürlüğü, Osmanlı Arşivi Daire Başkanlığı, Yay. Nu: 148. İstanbul: Seçil Ofset, 2017.

Basîretçi Ali Efendi. Istanbul'da Elli Yıllık Önemli Olaylar (İstanbul'da Yarım Asırlık Vekayi-i Mühimme, 1325), İstanbul: Sander Yayınları, 1976.

Başbakanlık Osmanlı Arşivi İrade Dahiliyye nr. 71819; 80070.

Beyatlı, Yahya Kemal. Eğil Dağlar, İstanbul: İstanbul Fetih Cemiyeti Yahya Kemal Enstitüsü, 1975.

Beyhan, Mehmet Ali. “Câbî Tarihi.” Doktora Tezi, İstanbul Üniversitesi Sosyal Bilimler Enstitüsü, 1992.Beyhan, Mehmet Ali. “II. Abdülhamid Döneminde Hafiyye Teşkilatı ve Jurnaller.” İlmî Araştırmalar, 8, (1999): 65-83.

Çalışkan, Çağrı. “II. Abdülhamid Döneminde Kitaplar Üzerinde Sansür Uygulamaları (1876-1909).” Yüksek Lisans Tezi, Pamukkale Üniversitesi Sosyal Bilimler Enstitüsü, 2019.

Çetin, Nurullah. Roman Çözümleme Yöntemi, Ankara: Öncü Basımevi, 2004.

Çetinsaya, Gökhan \& Buzpınar Ş. Tufan. "Midhat Paşa", İslâm Ansiklopedisi, 30, (İstanbul: Türkiye Diyanet Vakfi Yayınları, 2005), 7-11.

Çetinsaya, Gökhan. "II. Abdülhamid’in İç Politikası: Bir Dönemlendirme Denemesi." Osmanlı Araştırmalarl, The Journal of Ottoman Studies, XLVII, (2016): 353-409.

Enginün, İnci. Yeni Türk Edebiyatı Tanzimat'tan Cumhuriyet'e (1839-1923), İstanbul: Dergâh Yayınlar1, 2013. Demirel Fatmagül \& Çavaş Raşit. “II. Abdülhamid Dönemi’nde Gümrüklerde El Konulan (Ve Elbette Yakılan) Kitaplar." Müteferrika, 26, (2004): 151-158. 
Demirel, Fatmagül \& Çavaş Raşit. "Yeni Bulunan Belgelerin Işs̆ğında II. Abdülhamid'in Yaktırdığı Kitapların Bir Listesi." Müteferrika, 28, (2005): 3-23.

Demirel Fatmagül. II. Abdülhamid Döneminde Sansür, İstanbul: Bağlam Yayıncılık, 2007.

Devellioğlu, Ferit. Osmanlıca-Türkçe Ansiklopedik Lûgat, Ankara: Aydın Kitabevi Yayınları, 1993.

Georgeon, François. Sultan Abdülhamid, çev. Ali Berktay, İstanbul: İletişim Yayınları, 2012.

Gör, Emre. "II. Abdülhamid Dönemi’nden Bir İstihbaratçı Profili: Serhafiye Fehim Paşa (1873-1908).” Stratejik ve Sosyal Araştırmalar Dergisi,3/1, (2019): 71-84.

Güngör, Erol. Tarihte Türkler, İstanbul: Ötüken Yayınları, 1995.

Güntekin, Reşat Nuri. Kızılcık Dalları, İstanbul: İnkılâp Kitabevi, 2010.

. Değirmen, İstanbul: İnkılâp Kitabevi, 2010.

. Yeşil Gece, İstanbul: İnkılâp Kitabevi, 2013.

. Miskinler Tekkesi, İstanbul: İnkılâp Kitabevi, 2015.

. Dudaktan Kalbe, İstanbul: İnk1lâp Kitabevi, 2018.

. Acımak, çev. M. Fatih Kanter, İstanbul: İnk1lâp Kitabevi, 2018.

. Çalıkuşu, İstanbul: İnkılâp Kitabevi, 2019.

. Ateş Gecesi, İstanbul: İnkılâp Kitabevi, 8. Bask1.

. Son Sığınak, İstanbul: İnkılâp Kitabevi, 11. Baskı.

. Gökyüzü, İstanbul: İnk1lâp Kitabevi, 13. Bask1.

Gizli El, İstanbul: İnk1lâp Kitabevi, 13. Bask1.

Bir Kadın Düşmanı, İstanbul: İnkılâp Kitabevi, 17. Bask1.

. Damga, İstanbul: İnkılâp Kitabevi, 25. Bask1.

. Akşam Güneşi, İstanbul: İnkılâp Kitabevi, (ty.).

. Harabelerin Çiçeği, İstanbul: İnkılâp Kitabevi, (ty.).

Kavak Yelleri, İstanbul: İnk1lâp Kitabevi, (ty.).

Haydaroğlu, İlknur P. “II. Abdülhamit'in Hafiye Teşkilatı Hakkında Bir Risale.” Ankara Üniversitesi DTCF Tarih Araştırmaları Dergisi, 17/28, (1995): 109-133.

İnal, İbnülemin Mahmut Kemal. Son Sadrazamlar, 3, 3. Baskı, İstanbul: Dergâh Yayınları, 1987.

İrtem, Süleyman Kâni. Abdülhamid Devrinde Hafiyelik ve Sansür, Haz. Osman Selim Kocahanoğlu, İstanbul: Temel Yayınları, 1999.

Kaplan, Mehmet. Tevfik Fikret, İstanbul: Dergâh Yayınları, 1998.

Karakışla, Yavuz Selim. "II. Abdülhamid'in İstibdat Döneminde Jurnalciliğin Boyutları.” Toplumsal Tarih, 120, (2003a): 24-29.

Karakışla, Yavuz Selim. "Sultan II. Abdülhamid'in İstibdat Döneminde (1876-1909) Hafiyelik ve Jurnalcilik." Toplumsal Tarih, 119, (2003b): 12-21.

Kırl1, Cengiz. "Kahvehaneler ve Hafiyeler: 19. Yüzyıl Ortalarında Osmanlı'da Sosyal Kontrol.” Toplum ve Bilim, 83, (2000): 58-79.

Koloğlu, Orhan. Jurnal, Osmanlı Ansiklopedisi (Tarih, Medeniyet, Kültür). 7, İstanbul: İz Yayınları, 1996. 
Küçük, Cevdet. "II. Abdülhamid.” İslâm Ansiklopedisi, 1, İstanbul: Türkiye Diyanet Vakfı Yayınları, (1988): 216-224.

Mehmed Murâd. Müdâfaa Niyetine Bir Tecâvüz! (Kırk Anbar'a Cevâb), Paris: Meșveret Matbaas1, 1314.

Memâlik-i Mahrûsa-i Şâhâneye Duhûl ve İntişârı Memnu' Bulunan Kütüb ve Risâil-i Muzırrânın Esâmisini Mübeyyîn Cedveldir. Matbaa-i Osmânîye, İ.B.B. Atatürk Kitaplığı, 1900.

Mercan, Mehmet. "II. Abdülhamit Dönemine Ait Bir Jurnal Örneği: Sivas Valisi Halil Rıfat Paşa Hakkında Bir İhbârnâme.” Firat Üniversitesi Sosyal Bilimler Dergisi, 17/2, (2007): 341-369.

Parlatır, İsmail. Osmanlı Türkçesi Sözlüğü, Ankara: Yargı Yayınevi, 2010.

Tahsin Paşa. Abdülhamid ve Yıldız Hatıraları, İstanbul: Milliyet Matbaası, 1931.

Tanpınar, Ahmet Hamdi. Edebiyat Üzerine Makaleler, Haz. Zeynep Kerman, İstanbul: Dergâh Yayınları, 1992.

Tanpınar, Ahmet Hamdi. On Dokuzuncu Asır Türk Edebiyatı Tarihi, Haz. Abdullah Uçman, İstanbul: Dergâh Yayınları, 2013.

Tekin, Emrullah. "Hafiye.” İslâm Ansiklopedisi, 15, İstanbul: Türkiye Diyanet Vakfı Yayınları, (1997): 115-116. Tugay, Asaf. İbret, İstanbul: Sucuoğlu Matbaası, 1961.

Uzunçarşı11, İsmail Hakkı. Midhat Paşa ve Yıldız Mahkemesi, Ankara: Türk Tarih Kurumu Basımevi, 2000. https://www.hurriyet.com.tr/yazarlar/ilber-ortayli/2-abdulhamidi-gercekten-taniyor-muyuz-40230875 İlber

Ortaylı'nın 24.09.2016 tarihli yazısı (Son Erişim 31.07.2021)

\section{Görseller}

https://ozhanozturk.com/2018/07/27/midilli-lesvos-lesbos/ (Erişim: 01.07.2021)

https://archive.org/details/lesocialismeref02millgoog (Erişim: 07.07.2021)

https://tr.wikipedia.org/w/index.php?title=Dosya:Vatan_yahut_Silistre.pdf\&page=6 (Erişim: 10.07.2021)

https://www.fikriyat.com/galeri/tarih/ilk-turk-pulu-ve-sonrasinda-tedavule-cikarilan-osmanli-devleti-pullari/210

(Erişim: 12.07.2021)

https://i.redd.it/y2py5t4qatx41.png (Erişim: 14.07.2021)

http://www.eskiturkiye.net/4319/sinop-ve-sinop-kalesi (Erişim: 16.07.2021)

https://tr.wikipedia.org/wiki/Cezmi (Erişim: 18.07.2021) 